\title{
Clinical and preclinical imaging of hepatosplenic schistosomiasis
}

(1)

Brice Masi, Teodora-Adriana Perles-Barbacaru*, Monique Bernard and Angèle Viola*

(1)

CNRS, Aix-Marseille Université, CRMBM, Faculté des Sciences Médicales et Paramédicales la Timone, 27 boulevard Jean Moulin, Marseille, FRANCE.

*Correspondence: angele.viola@univ-amu.fr (A. Viola) and teodora.perles-barbacaru@univamu.fr (T. Perles-Barbacaru)

Keywords: hepatosplenic schistosomiasis, liver fibrosis, portal hypertension, clinical imaging, preclinical imaging, quantitative imaging methods

\section{Abstract}

Schistosomiasis, a neglected tropical disease, is a major cause of chronic morbidity and disability, and premature death. The hepatosplenic form of schistosomiasis is characterized by hepatosplenomegaly, liver fibrosis, portal hypertension and oesophageal varices, whose rupture may cause bleeding and death. We review currently available abdominal imaging modalities and describe their basic principles, strengths, weaknesses, and usefulness in the assessment of hepatosplenic schistosomiasis. Advanced imaging methods are presented that could be of interest for hepatosplenic schistosomiasis evaluation by yielding morphological, functional and molecular parameters of disease progression. We also provide a comprehensive view of preclinical imaging studies and current research objectives such as parasite visualisation in hosts, follow-up of host-immune response, and development of non-invasive quantitative methods for liver fibrosis assessment. 


\section{Hepatosplenic schistosomiasis}

27 Schistosomiasis, a waterborne helminthic disease is a major cause of chronic morbidity and premature death in Africa, South America, South East Asia, and Middle East, whereas imported cases have recently been on the rise in Europe. Schistosoma mansoni and Schistosoma japonicum are the main causative agents of hepatosplenic schistosomiasis (HSS). Schistosome eggs eliminated with mammalian excreta hatch in water and release miracidia that infect specific intermediate host snails. The gastropods shed on cercariae that can penetrate the skin of the human host. These larvae transform into schistosomulae, migrate to the venous circulation, and differentiate into sexually mature worms $[1,2]$. The eggs laid in the mesenteric vessels (S. mansoni, $S$. japonicum) migrate to the gastrointestinal tract and the liver. The host immune response leads to egg encapsulation within layers of immune cells embedded in extracellular matrix (ECM). Granuloma formation is a cause of chronic inflammation and fibrosis (Box 1) [1]. The diseases caused by S. mansoni and S. japonicum are divided in two stages, the acute and chronic phases. The acute syndrome generally occurs in the first infection, in the first months after exposure. In the chronic phase, two main clinical forms of schistosomiasis may occur, the hepatointestinal or the hepatosplenic disease [3].

The hepatosplenic complication occurs in less than $10 \%$ of patients, 5-20 years after infection $[4,5]$, owing to chronic granulomatous inflammation in the liver, leading to severe fibrosis of the portal system (Figure 1, Key Figure). Hepatomegaly is often an early sign of granulomatous inflammation $[1,6]$. Fibrosis in HSS occurs with little hepatocellular damage unlike cirrhosis (Box 1) $[5,7]$. The major complication of liver fibrosis is portal hypertension (PH) (Box 1), which causes splenomegaly and esophageal, gastric, splenorenal, pancreaticoduodenal and periumbilical varice formation. Esophageal varice bleeding is potentially fatal $[1,2,5,8]$. Other complications include anemia, thrombocytopenia, nephritic glomerulopathy, and pulmonary arterial hypertension with right heart failure $[1,2,5,8]$. Liver dysfunction may occur in cases 
51 of comorbidities (hepatitis, steatosis) (Box 1) [5] and in advanced-stage disease. HSS is associated with a higher incidence of hepatocellular carcinoma [2]. The diagnosis of parasite infection is generally based on fecal egg count (Kato-Katz technique) and requires sexually mature worms. Rectal mucosa biopsy for egg detection is performed when infection is suspected despite negative Kato-Katz tests. The diagnosis of HSS relies on clinical examination, liver biopsy and medical imaging. Changes in size and consistency of the liver and the spleen can be detected at palpation and percussion. Biopsy, the standard diagnostic technique is highly invasive and tissue sampling often inadequate to cover fibrosis heterogeneity. Ultrasonography (USG, see Glossary) is currently the most widely used technique to detect organomegaly and altered texture due to fibrosis $[9,10]$.

\section{Overview of imaging modalities and applications to HSS}

Imaging allows the assessment of HSS morbidity by diagnosing and staging fibrosis, evaluating vascular complications, guiding surgical interventions, and monitoring response to treatment. Improving fibrosis diagnosis and staging, especially early and mild forms, with non-invasive and quantitative methods is a major challenge in liver imaging, regardless of the cause of fibrosis. Preclinical imaging studies are essential to better characterize specific morphologic and functional changes linked to granulomatous inflammation. They are also required for the development and validation of imaging methods with improved sensitivity to early fibrosis, and for the identification of robust biomarkers translatable to the clinical setting.

This review provides an update on HSS imaging, covering clinical and research applications. After a methodological overview of abdominal imaging modalities, we discuss their utility in the diagnosis and follow-up of HSS. We describe multimodal approaches combining imaging techniques with elastography and the results obtained so far on HSS. We discuss the potential of advanced methods evaluated in the research setting that could take up the challenge of non- 
invasive quantitative assessment of fibrosis severity and vascular dysfunction. We also provide the first synthesis of preclinical imaging studies and present the main lines of research including parasite visualization in hosts, follow-up of host-immune response, and development of noninvasive quantitative methods for HSS assessment.

\section{Ultrasonography (USG)}

USG is the first-line medical imaging examination for the non-invasive exploration of gastrointestinal and hepatic diseases (Table 1). Real-time imaging of parenchymal texture, vascular anatomy and haemodynamics allows fast clinical interpretation as well as guidance of interventional procedures and monitoring response to therapy.

Due to its portability and cost-effectiveness, USG is also the most-widely used radiologic method to diagnose HSS (Table 2). Although HSS caused by S. mansoni and S. japonicum share common features, differences in fibrotic lesions have been described such as the "mosaics" formed by echogenic septa [11-14] in S. japonicum infection. The need for fibrosis scales specific for HSS and standardized USG methods for schistosomiasis exploration led to consensus guidelines. The landmark Niamey classification specific for the mansonian disease includes scores for liver parenchymal patterns, periportal fibrosis and PH [15]. Granulomatous inflammation is described as pattern B or "starry sky" (Figure 1) because of diffuse echogenic spots. Fibrosis along portal sub-branches is described in pattern C as "rings" and "pipestems" depending on the viewing angle, and as "bull's eye" on cross-sections with an anechogenic portal vein surrounded by echogenic fibrous tissue. Fibrosis can also be localized around the portal vein bifurcation as "ruff" (pattern D). USG permits to measure fibrosis thickness of second order branches, of the gallbladder as well as ruff thickness. In advanced forms, patches form around the hepatic portal vessels for pattern E and extend to the liver periphery as "Bird's claw" for pattern F. Combinations of patterns are possible (e.g. iDb, Dc, Ec). PH is evaluated by measuring portal vein diameter, second order branch dilation, splenic vein diameter and by 
detecting varices. Volumetric assessment of the liver is possible with newer USG systems.

Spleen enlargement and texture (homogenous or granular) can be evaluated. Ascites, masses such as cancers (pattern Z) or haemangioma can be detected. The differential diagnosis between cirrhosis and schistosomiasis is complicated by the presence of intraparenchymal fat $(e . g$. alcoholic and non-alcoholic steatosis) resulting in hyperechogenicity of the parenchyma. In this case, pattern $\mathrm{Y}$ is assigned. Systemic varices and portal vein thrombosis can be detected by analysing blood flow using Doppler ultrasound.

\section{Computed tomography $(C T)$}

110 CT is widely used to explore diffuse or focal digestive diseases (Table 1). There are few CT studies on liver fibrosis [16]. Analysis of texture features from CT images enables staging of

112 fibrosis throughout the liver, but is less accurate in case of heterogeneous fibrosis and considered inferior to ultrasound transient elastography (TE, FibroScan ${ }^{\circledR}$ ) [17]. PH can be

114 diagnosed by portal vein and mesenteric vein dilation, varices and organomegaly detectable with a single rapid scan. Repeated scanning during injection of mainly tri-iodinated benzene ring-containing contrast agents $(\mathbf{C A})$ allows identification of arterial, venous and perfusion

117 phases with the potential to detect perfusion changes occurring during fibrosis, but delivers

118 higher radiation dose. Increased parenchymal CA retention is observed in advanced fibrotic 119 tissue.

120 Unexpected hepatic and pancreatic lesions have been described in the acute phase of S. mansoni 121 infection together with hepatomegaly and splenomegaly [18] (Table 2). In mansonian HSS, the 122 main features of the fibrotic liver are round low-density periportal zones enhancing after CA 123 administration, and linear bands in longitudinal sections of portal veins [19]. In HSS caused by 124 S. japonicum, capsular and septal calcifications result in a "turtle back" appearance of the liver. 125 Fibrous septa are enhanced after CA injection [11-13, 20-22]. 
128 Anatomy, microstructure, vasculature, perfusion, and metabolism can be assessed with 129 magnetic resonance methods (Table 1). In the portal venous phase and the delayed venous 130 phase, unspecific extracellular gadolinium chelates enhance fibrous hepatic tissue, and improve texture analysis [23]. Clinically approved hepatocyte-specific CAs such as Gadoxetate Disodium (Gd-EOB-DTPA) employed for diagnosing and staging HCC are used to assess the residual liver tissue function in liver fibrosis [24].

134 MRI would provide more precise information than USG regarding periportal fibrosis, gallbladder fibrosis, and alterations of the abdominal venous system in HSS (Table 2) [4, 25]. Besides the detection of morphological anomalies suggestive of liver fibrosis and $\mathrm{PH}$ on anatomical images (splenomegaly, large portal vein diameter, varices, ascites...) [4, 14], granulomatous inflammation and liver fibrosis can be detected on CA-enhanced MRI, and various methods can be used to assess subtle changes in liver microstructure [26]

140 (Supplementary file).

Scintigraphy, single-photon emission computed tomography (SPECT), positron emission tomography $($ PET)

144 Although the main applications of nuclear medicine techniques are in oncology (Table 1), 145 scintigraphy can be used to stage $\mathrm{PH}$ and portosystemic shunts in chronic liver diseases [27], whereas ${ }^{18} \mathrm{~F}$-fluorocholine radiotracer seems promising for the grading of liver fibrosis [28].

147 Differentiation between cirrhotic and non-cirrhotic PH is possible with ${ }^{99 m}$ Tc-labelled sulphur 148 colloid particles but specific fibrosis patterns pathognomonic for schistosomiasis are not 149 discernible. Scintigraphy has been used in the post-operative follow-up of patients who underwent splenectomy followed by auto-implantation of spleen tissue [29, 30]. A case report 
described hypermetabolic pancreatic lesions with deoxy-2-( ${ }^{18}$ F)fluoro-D-glucose in HSS [31]. Interestingly, hepatic angioscintigraphy with ${ }^{99 \mathrm{~m} T c-l a b e l l e d ~ s u l p h u r ~ c o l l o i d ~ p a r t i c l e s ~ r e v e a l e d ~}$ increased hepatic perfusion index in patients with HSS, which was correlated with splenomegaly and oesophageal varices [32]. This finding would reflect an increased perfusion through the hepatic artery (Table 2).

\section{Endoscopy and laparoscopy}

Endoscopy can be used for diagnosis, biopsy, follow-up, and therapeutic purposes (e.g. laparoscopic surgery, image-guided embolization or ligation of varices) (Table 1).

HSS can be explored by endoscopy (Table 2) [33]. The cost and risk of infection linked to the invasiveness of the technique are limitations to its use in resource-limited countries. Endoscopy permits to view and treat collaterals, to identify ascites, $\mathrm{PH}$, whereas hepatomegaly, splenomegaly and granulomatous inflammation in liver can be detected with laparoscopy. Endoscopy is the gold-standard technique to guide ligation or sclerotherapy treatment of oesophageal varices. In HSS with PH, endoscopic sclerotherapy for esophageal varices was shown to be more efficient for secondary prophylaxis of upper gastrointestinal bleeding when preceded by splenectomy and esophagogastric devascularisation [34].

\section{Which imaging modality for which HSS stage?}

170 The acute stage is characterized by a syndrome with severe clinical manifestations including

171 hepatomegaly, splenomegaly and lymphadenopathy. The enlargement of the liver, the spleen

172 and abdominal lymph nodes can be visualized with USG [35]. When other sites of lesions are 173 suspected during this stage (e.g. central nervous system, lungs or intestines...), other imaging 174 modalities more appropriate for the exploration of these organs should be utilized (CT, MRI or 
not always permit to classify patients, especially if the time of infection is unknown. Moreover, there are frequent overlaps of the pathological signs of the acute and chronic stages, and of moderate and severe HSS (Table 2). Fibrosis and PH are common features of both moderate and severe HSS, but PH predominates in severe HSS and is associated with congestive splenomegaly and a high risk of variceal bleeding. Fibrosis grade is regarded as a predictive value for PH and esophageal varices. USG, the first line imaging modality, permits the detection of splenomegaly, fibrosis, and hemodynamic changes. Although USG can be used for fibrosis grading, it is not sensitive to mild disease, and often underestimates fibrosis in comparison to liver biopsy [14], and is sensitive to inflammation [35]. If available, conventional CT or MRI methods can be used to map fibrosis spatial distribution $[5,36]$. As for USG, the results may be affected by inflammation in early disease stages. Fibrogenesis and inflammation are generally concomitant processes and such indirect parameters are not sufficiently specific. (Supplementary file). Additional investigation can be performed with SWI to detect iron deposits in inflammatory processes. When using CT or MRI, additional hemodynamic parameters can be collected with DCE or ASL. All these methods are available on clinical MRI scanners.

\section{Emerging methods for human schistosomiasis assessment?}

\section{Evaluation of liver fibrosis}

Elastography - Elastography has become the most widely used method to detect liver fibrosis and cirrhosis consecutive to steatosis or viral hepatitis [37]. Elastography cannot be regarded as an emerging method, but so far only few studies have reported its use in HSS. 
In sonographic elastography, tissue excitation is either induced by acoustic radiation force impulse (ARFI) or using a mechanical vibrating device for TE. Pulse-echo acquisitions are performed to measure the velocity of the shear-wave, which informs about the elastic properties of the tissue. Few studies have explored HSS using sonographic elastography (Table 3) and only one used the ARFI method (Table 3). In patients with hepatitis C virus co-infection discrepancies between liver biopsy and ultrasonographic TE findings were identified [38, 39], probably due to fibrosis heterogeneity. In the absence of comorbidities, liver stiffness measurement (LSM) was higher in HSS patients than in controls and cirrhotic patients [40, 41].

One single study evaluating both liver and spleen stiffness reported a correlation between spleen stiffness and some USG signs of PH (portal vein diameter, area, and congestion index, splenic artery resistance index, splenic vein diameter and spleen diameter) [41]. In S. japonicum HSS, LSM was not correlated to USG findings [42]. These studies suggest that liver LSM could be a marker of HSS fibrosis. Moreover, spleen stiffness could assist in selecting patients for endoscopy. Indeed, it would be superior to liver stiffness in predicting esophageal varices [43]. However, ultrasound TE has several limitations, including a lack of reproducibility/reliability in case of steatosis, light fibrosis, obesity or ascites. Moreover, liver stiffness is affected by

217 inflammation, iron overload, blood flow, and venous congestion [37, 44, 45]. Mechanically generated shear waves propagating through the liver can also be detected using 219 motion-sensitive MRI techniques [37] implemented on standard MRI systems. Magnetic resonance elastography (MRE)-derived stiffness correlates with fibrosis stage in patients [46]. MRE appears more accurate and reliable than USG elastography to stage fibrosis [45, 47-50]

222 and allows better coverage of fibrosis heterogeneity [37], moreover it is reliable in case of 223 ascites. However, confounding comorbidities such as iron overload can limit the reliability of 224 MRE. 
225 Advanced MRI methods - MRI methods sensitive to Brownian water motion in tissues are used

226 to probe tissue microstructure. Diffusion-weighted imaging (based on Gaussian distribution of

227 water diffusion) with apparent diffusion coefficient (ADC) mapping, diffusion kurtosis imaging

228 (based on non-gaussian distribution of water diffusion) have been successfully applied to stage

229 moderate to advanced fibrosis in pre-cirrhotic liver with equal performance [51, 52]. Intravoxel

230 incoherent motion (IVIM) analysis which separately assesses parenchymal diffusion and

231 microvascular perfusion changes could be potentially more sensitive to pathophysiological

232 alterations during early fibrosis [53].

233 Double contrast-enhanced MRI using gadolinium-based CAs and SPIOs with or without texture

234 analysis has been used to differentiate early liver fibrosis from advanced disease with excellent

235 results $[23,54,55]$. Collagen fiber deposition in the space of Disse leads to an increase of the

236 extracellular space quantifiable as the distribution volume fraction of nonspecific CA in the

237 parenchymal (equilibrium) phase by MRI (or CT) [56-59]. Preclinical studies have shown that

238 the liver accumulation of collagen targeted CAs correlates with histological fibrosis scores [60].

239 Non-contrast enhanced relaxometric studies quantifying the longitudinal $\left(\mathrm{T}_{1}\right)$, transverse $\left(\mathrm{T}_{2} *\right)$

240 and combined $\left(\mathrm{T}_{1} \mathrm{Q}\right)$ magnetic relaxation time constants, which provide information on tissue

241 microstructure and macromolecule content, have shown a good correlation of these parameters

242 with liver fibrosis, without being specific for it [61-64]. (Supplementary file).

243 Phosphorus magnetic resonance spectroscopy $\left({ }^{31} P-M R S\right)$ - MRS is a non-invasive method for

244 monitoring cellular metabolism that can be performed during an MRI exploration. Spectra are

245 often acquired from a unique voxel (single voxel spectroscopy, SVS). MRS imaging (MRSI)

246 permits the simultaneous acquisition of multiple spectra in contiguous voxels and the

247 generation of metabolic maps providing spatial distribution of metabolite signals. ${ }^{31} \mathrm{P}-\mathrm{MRS}$

248 allows assessment of bioenergetics and phospholipid metabolism intermediates mainly

249 phosphomonoesters (PME) and phosphodiesters (PDE) (Box 1). An alteration of phospholipid 
metabolism in cirrhosis has been identified using SVS and MRSI techniques [65, 66]. Fibrosis

251

252 was associated with a decrease in PDE and the PME/(PME+PDE) ratio could separate mild from advanced fibrosis [65]. In another study, the PME/PDE ratio was strongly correlated with advanced fibrosis [66]. (Supplementary file).

\section{Assessment of vascular damage}

Detection of varices with non-invasive capsule endoscopy - Capsule endoscopy involving transit of an ingestible wireless camera along the digestive tract can be performed to visualise the entire small bowel when simultaneous therapeutic intervention or tissue sampling is not required. Capsule endoscopy has been successfully used in a pilot study to detect oesophageal varices in HSS and enabled the identification of small bowel lesions in PH together with edema, erosions and scarred mucosa $[67,68]$. Although clinically significant esophageal and rectal varices are typically visible endoscopically, ectopic varices may require cross sectional or multiplanar portal venous phase CT or MRI for diagnosis.

Assessment of liver perfusion - Besides the non-invasive delineation of hepatic vascular anatomy by CT and MRI angio- and portography, several methods can be used for the assessment of hemodynamic changes in liver pathologies, including cirrhotic or non-cirrhotic PH. Among them, dynamic contrast-enhanced (DCE) CT, MRI or USG, relying on CA injection and liver-specific tracer kinetic modelling, allows quantitative assessment of liver perfusion and separation of arterial and portal-venous phases $[69,70]$. DCE MRI studies showed that reduced portal perfusion was quantitatively related to fibrosis stage [71]. Hemodynamic parameters obtained from DCE imaging, such as increased mean transit time [72] and arterial blood flow [73], have the potential to detect perfusion changes occurring early during fibrosis. Non-invasive and quantitative tissue perfusion measurement can also be performed with arterial spin labelling (ASL) techniques without exogenous CA. These 
275 techniques developed for the heart, kidney and brain have been successfully applied to the liver.

276 A significant reduction in liver and spleen perfusion could be measured in cirrhosis [74, 75].

277 Although ASL has not yet been implemented in the clinical abdominal MRI routine, it

278 represents an alternative to standard DCE methods, when repeated measures are required or

279 when CA injection is contraindicated.

280 Quantitative MRI providing blood velocity in all directions and over the entire cardiac cycle,

281 now feasible within tenth of minutes, can depict altered flow patterns in the abdominal

282 vasculature, revealing PH and its consequences such as portocaval anastomoses less accessible

283 by USG, Doppler US or endoscopy.

284 MRI detection of splenic siderotic nodules - Diffusion MRI with ADC mapping of the spleen 285 [41] and magnetic susceptibility-weighted imaging (SWI) [76, 77] have been successfully used 286 to evaluate splenic signs of PH including splenic siderotic nodules (Gamna-Gandy bodies) (Box 287 1) with higher sensitivity than anatomical MRI. Although these nodules are a frequent sign (> $28865 \%$ ) of PH in HSS [78, 79], SWI which is sensitive to iron deposits, has not yet been applied 289 in HSS. SWI as well as quantitative susceptibility mapping (QSM) is also sensitive to 290 calcifications, which are frequent in S. japonicum infection, and to hemorrhages. SWI has 291 shown high accuracy for the grading of mild and advanced liver fibrosis [77, 80].

293 Pre-clinical imaging studies of schistosomiasis

\section{Animal models}

Models of schistosomiasis have been developed in different animal species providing the opportunity to study host immune response to schistosome infection, granulomatous inflammation, fibrogenesis, and to evaluate new therapies or vaccine candidates. Although they do not recapitulate all the features of the human disease, they remain clinically relevant as they develop liver fibrosis [81] and $\mathrm{PH}$ [82]. The characterization of experimental HSS with imaging 
methods is essential for the selection of appropriate models in pharmacological studies.

Preclinical studies aim at developing methods allowing direct visualisation and quantification of the parasites within host tissues, monitoring of host immune response to schistosome, detection, staging and quantification of liver fibrosis, and identification of markers for assessing anti-parasitic or anti-fibrotic drug efficacy (Table 4).

305

\section{Imaging parasites within host tissues}

307

In vivo visualisation of schistosomes at different developmental stages could help monitor parasite burden, detect ectopic localization and assess the schistosomicidal efficacy of new chemotherapies. Using fluorescence molecular tomography (FMT) [83] and microPET in mice, adult worms of different species (S. mansoni, S. japonicum and S. haematobium the agent of urogenital schistosomiasis) were directly visualized [84] and the anti-helminthic efficacy of several drugs could be monitored. FMT was used alone or in combination with microPET and MRI [85]. MicroPET studies showed that $\left({ }^{18} \mathrm{~F}\right) \mathrm{FDG}$ was taken up by $S$. mansoni worms in mice

314 (Table 4).

315 Confocal laser scanning microscopy combined with a lens system integrated in a rigid endoscope was tested for the visualisation of eggs within the gut mucosa of mice infected with S. mansoni [86]. Detection and differentiation between viable and dead eggs was achieved in 318 real time during endoscopy. Although performed on euthanized animals, this technique is a 319 potential substitute for invasive tissue sampling when stool specimens are negative in early infection or due to treatment. The technique was applied shortly after to detect eggs in the bladder mucosa of a S. haematobium infected patient [87]. Fluorescent CA targeting eggs could

322 possibly increase sensitivity of the endoscopic approach. 
324 Bioluminescence imaging (BLI), a method allowing direct visualisation of gene expression 325 through chemically-induced light emission [88, 89] was used to follow up eosinophilia and

326

327

329

330

331

332

333

334

335

336

337

338

339

340

341

342

343

344

345

346

347 eosinopoiesis in mice infected with $S$. mansoni and expressing a luciferase reporter driven by an eosinophil peroxidase promoter [90]. In another study, the dynamics of collagen deposition in S. japonicum infection were monitored in mice expressing luciferase under a collagen promotor [91]. Newly formed collagen was assessed in mice with and without praziquantel treatment after granuloma formation.

\section{Characterization of HSS and identification of imaging markers of fibrosis}

HSS has been investigated with SPECT/CT, MRI, and USG (Table 4). USG studies in $S$. japonicum infected mice, rabbits and pigs identified common features with the human disease including hepatomegaly, advanced liver fibrosis, and enlarged portal vein diameter. A longitudinal study of the mouse model provided further description of HSS including portal and splenic vein diameter, spleen and liver morphometry, liver fibrosis patterns, and intestinal wall thickening [92]. These studies confirmed the relevance of experimental models of S. japonicum infection in pathophysiological and pharmacological studies.

HSS in S. mansoni infection was investigated in experimental models (mice) and semi-captive chimpanzees. As for S. japonicum infection, the imaging studies demonstrated the relevance of these models to the characterization of HSS. A longitudinal study performed on S. mansoni infected mice using microSPECT/CT and a new radiotracer labeled with ${ }^{188} \operatorname{Re}\left({ }^{188} \mathrm{Re}-\mathrm{OCTAM}\right)$ binding to hepatocyte asialoglycoprotein receptors (Box 1) permitted to detect hepatic necrosis and fibrosis [93]. The first MRI study of S. mansoni infected mice [94] used anatomical MRI and identified a patchy liver pattern assigned to fibrosis at histology. A longitudinal MRI study of this model [95] revealed anatomical signs of PH (liver, spleen and portal vein enlargement) and contrast-enhancement of fibrotic liver lesions. Furthermore, this study proposed that 
quantitative mapping of the transverse $T_{2}$ relaxation time constant could be used to noninvasively assess fibrosis [95].

350

\section{Concluding remarks}

352 Assessment of HSS morbidity and treatment monitoring would benefit from non-invasive

353

354

355 imaging methods allowing reliable fibrosis staging and estimation of vascular dysfunction (see outstanding questions). Quantitative methods, which have been successfully evaluated on human fibrotic and cirrhotic liver (USG elastography, MRE, ${ }^{31} \mathrm{P}-\mathrm{MRS}, \mathrm{ASL}$, perfusion PET ...) or in experimental schistosomiasis ( $T_{2}$ mapping) have a potential for clinical/human schistosomiasis assessment provided the equipment is available. Advanced acquisition and post-processing methods under development aiming at identifying markers sensitive to early pathological mechanisms (inflammation, perfusion changes) and early fibrosis stages (e.g. IVIM, combined arterial and portal venous input DCE, double-contrast enhanced MRI) still require validation in schistosomiasis models. Moreover, the precise relationship between imaging markers (e.g. relaxation time constants or ADC) and pathophysiological changes accompanying chronic hepatic inflammation (iron accumulation and edema) as well as the possible contributions of confounding factors such as comorbidities (steatosis, hepatitis) need to be established. Non-invasive markers of hepatic fibrosis are increasingly needed in pharmacological studies prompting the development of advanced and standardized quantitative methods with translational potential in clinics.

Funding: this work was funded by CNRS (Centre National pour la Recherche Scientifique) and Aix-Marseille University. CRMBM is a member of France Life Imaging (grant ANR-11INBS-0006 from the French "Investissements d'Avenir" program). 
374

\section{References}

376 1. Ross, A.G. et al. (2002) Schistosomiasis. N Engl J Med 346 (16), 1212-20.

377 2. Colley, D.G. et al. (2014) Human schistosomiasis. Lancet 383 (9936), 2253-64.

378 3. Burke, M.L. et al. (2009) Immunopathogenesis of human schistosomiasis. Parasite Immunol $37931(4), 163-76$.

380

4. Lambertucci, J.R. et al. (2008) Imaging techniques in the evaluation of morbidity in 381 schistosomiasis mansoni. Acta Trop 108 (2-3), 209-17.

382

5. Lambertucci, J.R. (2014) Revisiting the concept of hepatosplenic schistosomiasis and its challenges using traditional and new tools. Rev Soc Bras Med Trop 47 (2), 130-6.

384

6. Gryseels, B. et al. (2006) Human schistosomiasis. Lancet 368 (9541), 1106-18.

7. Olveda, D.U. et al. (2014) The chronic enteropathogenic disease schistosomiasis. Int J Infect Dis $28,193-203$.

8. Andrade, Z.A. (2009) Schistosomiasis and liver fibrosis. Parasite Immunol 31 (11), 656-63.

9. Skelly, P.J. (2013) The use of imaging to detect schistosomes and diagnose schistosomiasis. Parasite Immunol 35 (9-10), 295-301.

390 10. Olveda, D.U. et al. (2014) Utility of Diagnostic Imaging in the Diagnosis and Management of Schistosomiasis. Clin Microbiol 3 (2).

11. Cheung, H. et al. (1996) The imaging diagnosis of hepatic schistosomiasis japonicum sequelae. Clin Radiol 51 (1), 51-5.

12. Fung, H.S. et al. (2009) Hepatic schistosomiasis. Hong Kong Med J 15 (1), 75-6. 

cases undergoing splenectomy. Hum Pathol 42 (1), 111-9.

15. Richter, J. et al., A Practical Guide to the Standardized Use of Ultrasonography for the Assessment of Schistosomiasis-related Morbidity, Ultrasound in schistosomiasis- Second 401 International Workshop Niamey, Niger, 1996.

402

16. Huber, A. et al. (2015) State-of-the-art imaging of liver fibrosis and cirrhosis: A 403 comprehensive review of current applications and future perspectives. Eur J Radiol Open 2, 404 90-100.

17. Martinez, S.M. et al. (2011) Noninvasive assessment of liver fibrosis. Hepatology 53 (1), 406 325-35.

407

18. Passos, M.C. et al. (2009) Ultrasound and CT findings in hepatic and pancreatic 408 parenchyma in acute schistosomiasis. Br J Radiol 82 (979), e145-7.

409 19. Fataar, S. et al. (1985) CT of hepatic schistosomiasis mansoni. AJR Am J Roentgenol 145 $410 \quad(1), 63-6$.

20. Manzella, A. et al. (2008) Schistosomiasis of the liver. Abdom Imaging 33 (2), 144-50.

21. Monzawa, S. et al. (1993) Schistosomiasis japonica of the liver: contrast-enhanced CT findings in 113 patients. AJR Am J Roentgenol 161 (2), 323-7.

414 22. Nepal, P. et al. (2019) Multisystem imaging review of human schistosomiasis: 415 characteristic imaging findings. Clin Imaging 54, 163-171.

416 23. Yokoo, T. et al. (2015) Evaluation of Liver Fibrosis Using Texture Analysis on Combined417 Contrast-Enhanced Magnetic Resonance Images at 3.0T. Biomed Res Int 2015, 387653.

418 24. Juluru, K. et al. (2017) Diagnostic accuracy of intracellular uptake rates calculated using 419 dynamic Gd-EOB-DTPA-enhanced MRI for hepatic fibrosis stage. J Magn Reson Imaging 45 (4), 1177-1185. 
25. Lambertucci, J.R. et al. (2004) Magnetic resonance imaging and ultrasound in

422 hepatosplenic schistosomiasis mansoni. Rev Soc Bras Med Trop 37 (4), 333-7.

423 26. Feier, D. et al. (2016) The diagnostic efficacy of quantitative liver MR imaging with 424 diffusion-weighted, SWI, and hepato-specific contrast-enhanced sequences in staging liver 425 fibrosis--a multiparametric approach. Eur Radiol 26 (2), 539-46.

426

27. Dragoteanu, M. et al. (2008) Staging of portal hypertension and portosystemic shunts

427 using dynamic nuclear medicine investigations. World J Gastroenterol 14 (24), 3841-8.

428

28. Kwee, S.A. et al. (2018) PET/CT with (18)F Fluorocholine as an Imaging Biomarker for

429 Chronic Liver Disease: A Preliminary Radiopathologic Correspondence Study in Patients with

430 Liver Cancer. Radiology 287 (1), 294-302.

431

29. Petroianu, A. et al. (2006) Late follow-up of patients submitted to subtotal splenectomy. Int J Surg 4 (3), 172-8.

30. Brandt, C.T. et al. (2012) Splenosis after splenectomy and spleen tissue autoimplantation:

434 Late followup study. J Indian Assoc Pediatr Surg 17 (3), 104-6.

435

31. Ye, S. et al. (2014) F-18 FDG hypermetabolism in mass-forming focal pancreatitis and old hepatic schistosomiasis with granulomatous inflammation misdiagnosed by PET/CT imaging. Int J Clin Exp Pathol 7 (9), 6339-44.

32. de Carvalho, B.T. et al. (2016) Increased Hepatic Arterial Blood Flow Measured by Hepatic Perfusion Index in Hepatosplenic Schistosomiasis: New Concepts for an Old Disease. Dig Dis Sci 61 (7), 2118-26.

33. De Cock, K.M. (1986) Hepatosplenic schistosomiasis: a clinical review. Gut 27 (6), 734-45.

34. Costa Lacet, C.M. et al. (2016) Schistosomal portal hypertension: Randomized trial comparing endoscopic therapy alone or preceded by esophagogastric devascularization and splenectomy. Ann Hepatol 15 (5), 738-44. 
445

446

447

448

449

450

451

452

453

454

455

456

457

458

459

460

461

462

463

464

465

466

467

35. Barata, C.H. et al. (1999) Abdominal ultrasound in acute schistosomiasis mansoni. Br J Radiol 72 (862), 949-52.

36. Voieta, I. et al. (2010) Imaging techniques and histology in the evaluation of liver fibrosis in hepatosplenic schistosomiasis mansoni in Brazil: a comparative study. Mem Inst Oswaldo Cruz 105 (4), 414-21.

37. Zhang, Y.N. et al. (2019) Liver fibrosis imaging: A clinical review of ultrasound and magnetic resonance elastography. J Magn Reson Imaging.

38. Esmat, G. et al. (2013) Fibroscan of chronic HCV patients coinfected with schistosomiasis. Arab J Gastroenterol 14 (3), 109-12.

39. Ramzy, I. et al. (2017) Impact of old Schistosomiasis infection on the use of transient elastography (Fibroscan) for staging of fibrosis in chronic HCV patients. Acta Trop 176, 283287.

40. Carvalho Santos, J. et al. (2018) Liver ultrasound elastography for the evaluation of periportal fibrosis in schistosomiasis mansoni: A cross-sectional study. PLoS Negl Trop Dis 12 (11), e0006868.

41. Veiga, Z.S.T. et al. (2017) Transient elastography evaluation of hepatic and spleen stiffness in patients with hepatosplenic schistosomiasis. Eur J Gastroenterol Hepatol 29 (6), 730-735. 42. Wu, S. et al. (2018) Evaluation of transient elastography in assessing liver fibrosis in patients with advanced schistosomiasis japonica. Parasitol Int 67 (3), 302-308.

43. Ma, X. et al. (2016) Spleen Stiffness Is Superior to Liver Stiffness for Predicting Esophageal Varices in Chronic Liver Disease: A Meta-Analysis. PLoS One 11 (11), e0165786.

44. Yoshioka, K. et al. (2008) Transient elastography: Applications and limitations. Hepatol Res $38(11), 1063-8$. 

30.

471

46. Huwart, L. et al. (2006) Liver fibrosis: non-invasive assessment with MR elastography. NMR 472 Biomed $19(2), 173-9$.

Resonance Elastography with Acoustic Radiation Force Impulse Elastography for Pre-operative 475 Staging of Hepatic Fibrosis in Patients with Hepatocellular Carcinoma. Ultrasound Med Biol 43 (12), 2783-2790.

477

48. Chen, J. et al. (2017) Diagnostic Performance of MR Elastography and Vibration-controlled Transient Elastography in the Detection of Hepatic Fibrosis in Patients with Severe to Morbid Obesity. Radiology 283 (2), 418-428.

480 49. Imajo, K. et al. (2016) Magnetic Resonance Imaging More Accurately Classifies Steatosis 481 and Fibrosis in Patients With Nonalcoholic Fatty Liver Disease Than Transient Elastography. Gastroenterology 150 (3), 626-637.e7.

50. Park, C.C. et al. (2017) Magnetic Resonance Elastography vs Transient Elastography in 484 Detection of Fibrosis and Noninvasive Measurement of Steatosis in Patients With BiopsyProven Nonalcoholic Fatty Liver Disease. Gastroenterology 152 (3), 598-607.e2.

51. Taouli, B. et al. (2007) Diffusion-weighted MRI for quantification of liver fibrosis:

487 preliminary experience. AJR Am J Roentgenol 189 (4), 799-806.

488 52. Yang, L. et al. (2018) Staging liver fibrosis with DWI: is there an added value for diffusion 489 kurtosis imaging? Eur Radiol 28 (7), 3041-3049.

490 53. Chow, A.M. et al. (2012) Liver fibrosis: an intravoxel incoherent motion (IVIM) study. J 
492

493

494

495

496

497

498

499

500

501

502

503

504

505

506

507

508

509

510

511

512

513

514

515

54. Yu, J.S. et al. (2010) Double contrast-enhanced MRI of viral hepatitis-induced cirrhosis: correlation of gross morphological signs with hepatic fibrosis. Br J Radiol 83 (987), 212-7.

55. Bahl, G. et al. (2012) Noninvasive classification of hepatic fibrosis based on texture parameters from double contrast-enhanced magnetic resonance images. J Magn Reson Imaging 36 (5), 1154-61.

56. Ramachandran, P. et al. (2019) Assessment of liver T1 mapping in fontan patients and its correlation with magnetic resonance elastography-derived liver stiffness. Abdom Radiol (NY) 44 (7), 2403-2408.

57. Luetkens, J.A. et al. (2018) Quantification of Liver Fibrosis at T1 and T2 Mapping with Extracellular Volume Fraction MRI: Preclinical Results. Radiology 288 (3), 748-754.

58. Wang, H.Q. et al. (2019) Assessing liver fibrosis in chronic hepatitis B using MR extracellular volume measurements: Comparison with serum fibrosis indices. Magn Reson Imaging 59, 3945.

59. Zissen, M.H. et al. (2013) Contrast-enhanced CT quantification of the hepatic fractional extracellular space: correlation with diffuse liver disease severity. AJR Am J Roentgenol 201 (6), 1204-10.

60. Polasek, M. et al. (2012) Molecular MR imaging of liver fibrosis: a feasibility study using rat and mouse models. J Hepatol 57 (3), 549-55.

61. Hoad, C.L. et al. (2015) A study of T(1) relaxation time as a measure of liver fibrosis and the influence of confounding histological factors. NMR Biomed 28 (6), 706-14.

62. Banerjee, R. et al. (2014) Multiparametric magnetic resonance for the non-invasive diagnosis of liver disease. J Hepatol 60 (1), 69-77.

63. Liang, J. et al. (2018) Using IVIM-MRI and R2 Mapping to Differentiate Early Stage Liver Fibrosis in a Rat Model of Radiation-Induced Liver Fibrosis. Biomed Res Int 2018, 4673814. 
517 progression and regression: an experimental study in rats with carbon tetrachloride

518 intoxication. Eur Radiol 22 (8), 1709-16.

519 65. Noren, B. et al. (2008) Separation of advanced from mild fibrosis in diffuse liver disease 520 using 31P magnetic resonance spectroscopy. Eur J Radiol 66 (2), 313-20.

66. Traussnigg, S. et al. (2017) Ultra-high-field magnetic resonance spectroscopy in non-

522 alcoholic fatty liver disease: Novel mechanistic and diagnostic insights of energy metabolism

523 in non-alcoholic steatohepatitis and advanced fibrosis. Liver Int 37 (10), 1544-1553.

524 67. Ganc, R.L. et al. (2010) Small-bowel lesions caused by portal hypertension of schistosomal 525 origin: a capsule endoscopy pilot study. Gastrointest Endosc 71 (4), 861-6.

526 68. Baekby, M. et al. (2017) Hepatosplenic schistosomiasis: playing hide-and-seek with an 527 elusive parasite. BMJ Case Rep 2017.

69. Koh, T.S. et al. (2008) Hepatic metastases: in vivo assessment of perfusion parameters at dynamic contrast-enhanced MR imaging with dual-input two-compartment tracer kinetics model. Radiology 249 (1), 307-20.

531 70. Frohlich, E. et al. (2015) Dynamic contrast-enhanced ultrasound for quantification of tissue perfusion. J Ultrasound Med 34 (2), 179-96.

533 71. Leporq, B. et al. (2012) 3D-liver perfusion MRI with the MS-325 blood pool agent: a noninvasive protocol to asses liver fibrosis. J Magn Reson Imaging 35 (6), 1380-7. 72. Ronot, M. et al. (2010) Liver fibrosis in chronic hepatitis C virus infection: differentiating minimal from intermediate fibrosis with perfusion CT. Radiology 256 (1), 135-42. 73. Chen, B.B. et al. (2012) Dynamic contrast-enhanced magnetic resonance imaging with Gd- 
541 quantitative magnetic resonance imaging. J Hepatol 65 (6), 1131-1139.

542 75. Bradley, C.R. et al. (2018) Multi-organ assessment of compensated cirrhosis patients using 543 quantitative magnetic resonance imaging. J Hepatol 69 (5), 1015-1024.

544 76. Zhang, J. et al. (2013) Gamna-Gandy bodies of the spleen detected with susceptibility 545 weighted imaging: maybe a new potential non-invasive marker of esophageal varices. PLoS $546 \quad$ One $8(1)$, e55626.

547 77. Li, C. et al. (2013) Magnetic resonance susceptibility-weighted imaging versus other 548 imaging modalities in detecting splenic siderotic lesions. PLoS One 8 (9), e73626.

549 78. Bezerra, A.S. et al. (2007) Chronic hepatosplenic schistosomiasis mansoni: magnetic 550 resonance imaging and magnetic resonance angiography findings. Acta Radiol 48 (2), 125-34. 551 79. Bezerra, A.S. et al. (2008) Differentiating cirrhosis and chronic hepatosplenic 552 schistosomiasis using MRI. AJR Am J Roentgenol 190 (3), W201-7.

553 80. Balassy, C. et al. (2014) Susceptibility-weighted MR imaging in the grading of liver fibrosis: 554 a feasibility study. Radiology 270 (1), 149-58.

555 81. Andrade, Z.A. et al. (1997) An experimental approach to the pathogenesis of "pipestem" 556 fibrosis (Symmers' fibrosis of the liver). Mem Inst Oswaldo Cruz 92 (5), 699-706.

557 82. Sarin, S.K. et al. (1991) Hyperdynamic circulation in a chronic murine schistosomiasis 558 model of portal hypertension. Hepatology 13 (3), 581-4.

559 83. Stuker, F. et al. (2011) Fluorescence molecular tomography: principles and potential for 560 pharmaceutical research. Pharmaceutics 3 (2), 229-74.

561 84. Krautz-Peterson, G. et al. (2009) Imaging schistosomes in vivo. Faseb j 23 (8), 2673-80.

562 85. Salem, N. et al. (2010) In vivo imaging of schistosomes to assess disease burden using 563 positron emission tomography (PET). PLoS Negl Trop Dis 4 (9). 
86. Holtfreter, M.C. et al. (2011) Confocal laser scanning microscopy for detection of

565 Schistosoma mansoni eggs in the gut of mice. PLoS One 6 (4), e18799.

566 87. Fritzsche, C. et al. (2012) Confocal laser scanning microscopy, a new in vivo diagnostic tool 567 for schistosomiasis. PLoS One 7 (4), e34869.

568 88. Suff, N. and Waddington, S.N. (2017) The power of bioluminescence imaging in 569 understanding host-pathogen interactions. Methods 127, 69-78.

570 89. Mezzanotte, L. et al. (2017) In Vivo Molecular Bioluminescence Imaging: New Tools and 571 Applications. Trends Biotechnol 35 (7), 640-652.

572 90. Davies, S.J. et al. (2005) In vivo imaging of tissue eosinophilia and eosinopoietic responses 573 to schistosome worms and eggs. Int J Parasitol 35 (8), 851-9.

574 91. Harvie, M.C.G. et al. (2019) Live imaging of collagen deposition during experimental 575 hepatic schistosomiasis and recovery: a view on a dynamic process. Lab Invest 99 (2), 231-243. 92. Maezawa, K. et al. (2018) Real-time observation of pathophysiological processes during

577 murine experimental Schistosoma japonicum infection using high-resolution ultrasound 578 imaging. Trop Med Health 46, 1.

579 93. Cheng, P.C. et al. (2013) Evaluating the potential of a new isotope-labelled glyco-ligand for 580 estimating the remnant liver function of schistosoma-infected mice. Parasite Immunol 35 (3-

581 4), 129-139.

582

94. Kosaka, M. et al. (2000) In vivo NMR micro-imaging of kidney and liver of mouse at 9.4 T.

583 Jpn J Physiol 50 (4), 463-7.

584 95. Masi, B. et al. (2015) In Vivo MRI Assessment of Hepatic and Splenic Disease in a Murine 585 Model of Schistosomiasis [corrected]. PLoS Negl Trop Dis 9 (9), e0004036.

586 96. Schuppan, D. et al. (2018) Liver fibrosis: Direct antifibrotic agents and targeted therapies. Matrix Biol 68-69, 435-451. 
588 97. Suk, K.T. (2014) Hepatic venous pressure gradient: clinical use in chronic liver disease. Clin 589 Mol Hepatol 20 (1), 6-14.

590 98. Bonnard, P. et al. (2015) Comparison of liver biopsy and noninvasive techniques for liver 591 fibrosis assessment in patients infected with HCV-genotype 4 in Egypt. J Viral Hepat 22 (3), $592 \quad 245-53$.

593 99. Kardorff, R. et al. (2003) Validation of ultrasonography for hepatic schistosomiasis using a 594 porcine Schistosoma japonicum model. Acta Trop 85 (3), 315-23.

595 100. Standley, C.J. et al. (2013) Intestinal schistosomiasis in chimpanzees on Ngamba Island, 596 Uganda: observations on liver fibrosis, schistosome genetic diversity and praziquantel 597 treatment. Parasitology 140 (3), 285-95.

598 101. Liang, X.L. and Yuan, J.Y. (2013) Effect of Chinese herbal compound on liver fibrosis in 599 rabbits with schistosomiasis by B-ultrasound. Asian Pac J Trop Med 6 (8), 658-62.

600

601 


\section{HIGHLIGHTS}

603

604

605

606

607

608

609

610

611

612

613

614

615

616

617

618

619

620

621

622

623

624 the luciferase substrate is injected to the animals, its oxidation results into detectable light

625

- Liver fibrosis and portal hypertension in HSS may lead to variceal bleeding.

- Fibrogenesis in HSS differs from fibrogenesis of other etiology and requires specific and sensitive markers covering fibrosis heterogeneity. Currently no imaging markers are specific for HSS.

- USG is the leading imaging modality for HSS diagnosis, but other diagnostic imaging techniques can quantify liver fibrosis.

- Quantitative markers of HSS (collagen, iron and calcium deposition, microvascular density and flow) became accessible by medical imaging modalities.

- Semiquantitative and quantitative imaging markers for the assessment of vascular and hemodynamic alterations constitute valuable markers for staging, prognosis and treatment response.

- Preclinical imaging studies of HSS contribute to the development of clinically transferable markers sensitive to granulomatous inflammation and mild fibrosis.

GLOSSARY

Arterial spin labelling (ASL): Quantitative microvascular perfusion MRI technique relying on magnetically labeled arterial blood water molecules as endogenous tracer.

Bioluminescence imaging (BLI): whole-animal imaging method requiring the introduction of a bioluminescent reporter gene (e.g. firefly luciferase gene) fused to a gene of interest. When emission. 
626 Contrast agents (CA): mostly intravenously injected small molecules, which have the capacity

627 to enhance tissue contrast by modifying signal intensity upon accumulation. MRI CAs:

628 paramagnetic agents modifying the relaxation of neighbouring water protons. CT CAs contain 629 atoms with high atomic number increasing local photoelectric absorption. USG CAs: gas630 containing microbubbles.

631 Deoxy-2-( ${ }^{18}$ F)fluoro-D-glucose: a non-metabolizable glucose derivative used as radiotracer to assess glucose uptake in activated cells with PET imaging.

Diffusion MRI: unique imaging modality capable of probing tissue microstructure by measuring the water diffusivity which is hindered by biological barriers (e.g. cell membranes).

Dynamic contrast enhancement (DCE): following intravenous injection of a CA bolus, different phases of signal changes occur that are analysed using a pharmacokinetic model. The main phases are the arterial, portal venous and parenchymal phase in chronological order providing information about microvascular hemodynamics and CA distribution volume.

Elastography: method allowing the quantification of tissue stiffness (resistance to deformation) following the propagation of a mechanical strain or shear wave.

641 Fluorescence molecular tomography (FMT): whole-animal imaging method requiring the

642 injection of a fluorescent dye and irradiation with an excitation laser to generate light emission.

643 Intravoxel incoherent motion (IVIM): a mathematical model distinguishing two 644 contributions to the total tissue diffusivity in diffusion MRI: the microvascular 645 (pseudodiffusivity $\mathrm{D}^{*}$ weighted by the perfusion fraction $\mathrm{f}_{\mathrm{IVIM}}$ ) and the extravascular diffusivity 646 D.

647 Magnetic resonance spectroscopy (MRS): a spectroscopic modality allowing to identify and 648 to quantify biochemical molecules by analysing the resonance frequency of electromagnetic 649 waves emitted by atomic nuclei with magnetic properties such as ${ }^{1} \mathrm{H}$ and ${ }^{31} \mathrm{P}$. 

susceptibility generated by the presence of para- and diamagnetic compounds and obtained by deconvolution of the magnetic field distributions in $\mathrm{T}_{2} *$ weighted MRI

Relaxometry: measurement of magnetic relaxation time constants describing the return to equilibrium of excited nuclei (longitudinal $\mathrm{T}_{1}$, (true) transverse $\mathrm{T}_{2}$, (observed) transverse $\mathrm{T}_{2}{ }^{*}$, mixed $T_{1} \rho$. Magnetic relaxation is affected by molecule mobility and environment.

Voxel: volume element equivalent to a three-dimensional pixel.

\section{Box 1. Liver fibrosis and portal hypertension in hepatosplenic schistosomiasis}

659

Liver fibrogenesis is a wound-healing process activated by an inflammatory trigger and perpetuated by chronic inflammation. In schistosomiasis, a moderate Th1 response occurs, followed by a shift to a strong Th2 response elicited by egg antigens. The eggs become surrounded by immune cells. IL13 stimulates hepatic stellate cells (HSCs), the major ECMproducing cells, serving as vitamin A reservoirs and modulating vascular resistance and sinusoidal blood flow. Sinusoids are fenestrated vessels receiving blood from terminal hepatic arterioles and portal venules and delivering oxygen and nutrients to hepatocytes. Quiescent HSCs located in the space of Disse separating sinusoidal endothelial cells from adjacent hepatocytes and containing connective tissue trans-differentiate into phenotype-like myofibroblasts with increased contractile properties. They lose their vitamin A-containing lipid droplets and secrete fibrous collagens, fibronectin and proteoglycans, together with matrix metalloproteinases (MMPs) degrading ECM and tissue inhibitors of metalloproteinases

671 (TIMPs) regulating their proteolytic activity. The imbalance between ECM synthesis and 672 degradation progressively leads to replacement of liver tissue by a fibrous scar (fibrosis), 673 resulting in increased liver stiffness and distorted vascular architecture. Fibrosis is potentially 674 reversible, even in advanced stages. The therapeutic strategies explored to reverse fibrosis 
675 target either the inhibition of fibrogenetic mechanisms or fibrolysis but clinical validation is 676 needed [96]. Grading scales for fibrosis based on histology (e.g. METAVIR score) or serum 677 markers exist but are not specific for schistosomiasis. Cirrhosis is the end-stage of liver fibrosis 678 and is characterized by regenerative nodule formation, distorted hepatic vasculature, portal 679 hypertension and liver dysfunction.

680 Portal hypertension is the main complication of liver fibrosis and is defined by an elevation of 681 the hepatic venous pressure gradient (HVPG) above $5 \mathrm{mmHg}$. A value of $10 \mathrm{mmHg}$ is 682 indicative of clinically patent $\mathrm{PH}$ with a high risk of developing varices [97]. In HSS, periportal 683 fibrosis and granulomatous thrombophlebitis lead to progressive presinusoidal blood flow 684 obstruction (terminal portal venules level) and increased hepatic resistance causing $\mathrm{PH}$. $\mathrm{PH}$ is 685 complicated by congestive splenomegaly, formation of Gamna-Gandy bodies containing iron 686 and calcium inclusions, varices, destruction of the main portal vein branches despite the development of portosystemic collateral blood flow that may partly decompress the portal system and at end-stage by life-threatening variceal bleeding. Gastrointestinal bleeding is often the first clinical sign of $\mathrm{PH}$. The management of $\mathrm{PH}$ may be pharmacological with the prophylactic administration of $\beta$-blocker propanolol, or surgical with portacaval shunt, varice devascularization and splenectomy, distal splenorenal shunt, or with endoscopic sclerotherapy or ligation.

693

\section{OUTSTANDING QUESTIONS}

696

- $\quad$ Some patients progress to severe HSS, while patients with strong immunologic modulation capacity develop less severe (intestinal or hepatointestinal) variants of the chronic disease. Can imaging examinations of hepatic manifestations of acute schistosomiasis have prognostic potential? 
- How reliable is the non-invasive imaging assessment of fibrosis at early stages of the disease?

- $\quad$ Can we disentangle confounding factors to quantitative fibrosis markers (e.g. comorbidities, inflammation, iron overload)?

705

- $\quad$ Is a detailed classification equivalent to the Niamey USG classification (made for $S$. mansoni infection) needed for S. japonicum HSS?

- $\quad$ Should the Niamey USG classification be refined to include novel measurable markers by more advanced USG equipment (e.g. hemodynamics, vascular morphology, microbubble contrast enhancement, DCE)?

710

- Will the establishment of new guidelines and standardized protocols for imaging modalities other than USG be of diagnostic and prognostic utility?

712 What is the (multiparametric) imaging protocol best suited for reliable diagnosis and staging of HSS patients? assessment of hemodynamic alterations in HSS? 
Table 1. General features of clinical abdominal imaging modalities

\begin{tabular}{|c|c|c|c|c|c|c|}
\hline & USG & CT & MRI & $\begin{array}{c}\text { Scintigraphy+ } \\
\text { SPECT }\end{array}$ & PET & Endoscopy/Laparoscopy \\
\hline Portability & Yes & No & No & No & No & $\begin{array}{c}\text { Portable equipment used in } \\
\text { surgical setting }\end{array}$ \\
\hline $\begin{array}{l}\text { Cost of } \\
\text { equipment }\end{array}$ & $\approx 30 \mathrm{k} \$$ & $\approx 1 \mathrm{M} \$$ & $>1 \mathrm{M} \$$ & $\gamma$-camera $\approx 0.5 \mathrm{M} \$$ & $\mathrm{PET}+\mathrm{CT} \approx 2 \mathrm{M} \$$ & $<25 \mathrm{k} \$$ \\
\hline Invasiveness & No* & No* & No* & Yes & Yes & Yes, anesthesia required \\
\hline $\begin{array}{l}\text { Scanning/exam } \\
\text { time }\end{array}$ & $\begin{array}{l}\text { Real-time imaging / } 5 \text { - } \\
20 \mathrm{~min}\end{array}$ & $30 \mathrm{~s} / 10 \mathrm{~min} * *$ & $5 / 30 \min ^{* *}$ & $30 \mathrm{~min} / 4 \mathrm{~h}$ & $\begin{array}{l}20 \mathrm{~min} / \text { radionuclide } \\
\text { injected } 1 \mathrm{~h} \text { before }\end{array}$ & $\begin{array}{c}\text { Real-time imaging/ 1-2 } \mathrm{h} \text { for } \\
\text { preparation }\end{array}$ \\
\hline $\begin{array}{l}\text { Basic principle / } \\
\text { type of } \\
\text { radiation-tissue } \\
\text { interaction }\end{array}$ & $\begin{array}{l}\text { Propagation of pulses of } \\
\text { ultra-high frequency (1 } \\
\text { to } 20 \mathrm{MHz} \text { ) acoustic } \\
\text { waves. } \\
\text { US reflection at tissue } \\
\text { interfaces with differing } \\
\text { impedances and their } \\
\text { diffusion in tissue } \\
\text { parenchyma provide }\end{array}$ & $\begin{array}{l}\text { External irradiating } \\
\text { tomographic } \\
\text { method using X- } \\
\text { ray photon } \\
\text { transmission to } \\
\text { obtain image } \\
\text { contrast based on } \\
\text { the attenuation }\end{array}$ & $\begin{array}{l}\text { Absorption and reemission of } \\
\text { radiofrequency electromagnetic } \\
\text { waves by nuclear magnetic } \\
\text { resonance of tissue hydrogen when } \\
\text { placed in a strong external } \\
\text { magnetic field. Image contrast is } \\
\text { obtained by magnetic relaxation, } \\
\text { local susceptibility differences and }\end{array}$ & \begin{tabular}{|} 
Internal irradiating \\
method involving the \\
injection of labelled \\
biomolecules \\
(radiotracers) and \\
based on the detection \\
of the emitted $\gamma$-ray \\
photons after \\
distribution.
\end{tabular} & $\begin{array}{l}\text { Internal irradiating } \\
\text { method involving the } \\
\text { injection of labelled } \\
\text { biomolecules } \\
\text { (radiotracers) and } \\
\text { based on the } \\
\text { detection of } \gamma \text {-ray } \\
\text { photons emitted in } \\
\text { the annihilation }\end{array}$ & $\begin{array}{l}\text { Introduction of flexible or rigid } \\
\text { tubes into internal hollow } \\
\text { organs or cavities conducting } \\
\text { visible light via optic fibres for } \\
\text { endoluminal images of } \\
\text { epithelium. }\end{array}$ \\
\hline
\end{tabular}




\begin{tabular}{|c|c|c|c|c|c|c|}
\hline & $\begin{array}{l}\text { morphological } \\
\text { information in } \\
\text { brightness (B) mode. } \\
\text { The Doppler frequency } \\
\text { shift of the wave } \\
\text { reflected by blood cells } \\
\text { provides hemodynamic } \\
\text { information. }\end{array}$ & $\begin{array}{c}\text { coefficients of the } \\
\text { tissues. }\end{array}$ & $\begin{array}{l}\text { water motion due to flow, } \\
\text { diffusion or tissue deformation. }\end{array}$ & & $\begin{array}{l}\text { process between } \\
\text { positrons from the } \\
\text { radiotracer with } \\
\text { electrons from tissue. }\end{array}$ & \\
\hline $\begin{array}{l}\text { Principal } \\
\text { imaging } \\
\text { applications }\end{array}$ & $\begin{array}{l}\text { Anatomical imaging } \\
\text { (tissue interfaces, } \\
\text { echogenicity, texture) } \\
\text { Functional imaging } \\
\text { Image-guided intervention }\end{array}$ & $\begin{array}{l}\text { Anatomical } \\
\text { imaging } \\
\text { Perfusion imaging } \\
\text { Image-guided } \\
\text { intervention }\end{array}$ & $\begin{array}{c}\text { Multiparametric anatomical } \\
\text { imaging } \\
\text { Functional/physiological imaging } \\
\text { Metabolic imaging } \\
\text { Image-guided intervention }\end{array}$ & $\begin{array}{c}\text { Functional / } \\
\text { physiological imaging } \\
\text { Metabolic imaging } \\
\text { Image-guided } \\
\text { intervention }\end{array}$ & $\begin{array}{c}\text { Functional / } \\
\text { physiological } \\
\text { imaging } \\
\text { Metabolic imaging } \\
\text { Image-guided } \\
\text { intervention }\end{array}$ & $\begin{array}{l}\text { Anatomical imaging of tissue } \\
\text { surfaces } \\
\text { Image-guided intervention }\end{array}$ \\
\hline $\begin{array}{l}\text { Use of contrast } \\
\text { agents (CA) } \\
\text { or radiotracers } \\
\text { (RT) }\end{array}$ & $\begin{array}{l}\text { CEUS with injection of } \\
\text { microbubbles as } \\
\text { reticuloendothelial or } \\
\text { blood pool CA for the } \\
\text { characterization of focal } \\
\text { liver lesions, vascular }\end{array}$ & $\begin{array}{l}\text { CA: mainly non- } \\
\text { specific iodine - } \\
\text { containing agents }\end{array}$ & $\begin{array}{l}\text { CA: non-specific extracellular } \\
\text { gadolinium chelates for perfusion } \\
\text { imaging and parenchymal contrast } \\
\text { enhancement, } \\
\text { hepatocyte-specific gadolinium } \\
\text { and }\end{array}$ & $\begin{array}{l}\text { RT: }{ }^{99 \mathrm{~m}} \mathrm{Tc} \text { labelled } \\
\text { molecules most } \\
\text { widely used }\end{array}$ & $\begin{array}{c}\text { RT: }{ }^{18} \mathrm{~F},{ }^{15} \mathrm{O},{ }^{13} \mathrm{~N},{ }^{11} \mathrm{C} \\
\text { labelled molecules } \\
\text { (ie: }{ }^{18} \mathrm{~F} \text { 2-Deoxy } \\
\text { Glucose) }\end{array}$ & $\begin{array}{c}\text { Topically or systemically } \\
\text { administered targeted fluorescent } \\
\text { CA for molecular endoscop }\end{array}$ \\
\hline
\end{tabular}




\begin{tabular}{|c|c|c|c|c|c|c|}
\hline & $\begin{array}{l}\text { imaging and therapy } \\
\text { monitoring }\end{array}$ & & $\begin{array}{l}\text { manganese chelates taken up by } \\
\text { functioning hepatocytes only, } \\
\text { superparamagnetic iron oxide } \\
\text { (SPIO) particles targeting Kupffer } \\
\text { cells }\end{array}$ & & & \\
\hline $\begin{array}{l}\text { Spatial } \\
\text { resolution } \\
\text { (range) }\end{array}$ & $\begin{array}{c}0.3 \text { to } 1.5 \mathrm{~mm} \\
\text { depending on US } \\
\text { frequency }\end{array}$ & $\begin{array}{l}0.3 \text { to } 1 \mathrm{~mm} \\
\text { depending on } \mathrm{X} \text { - } \\
\text { ray tube } \\
\text { dimensions and } \\
\text { detector size }\end{array}$ & $\begin{array}{c}0.5 \text { to } 3 \mathrm{~mm} \text { depending on } \\
\text { acquisition time, magnetic field } \\
\text { strength and gradient coils }\end{array}$ & $\begin{array}{c}5 \text { to } 12 \mathrm{~mm} \text { depending } \\
\text { on collimator and } \\
\text { detector system }\end{array}$ & $\begin{array}{l}4 \text { to } 10 \mathrm{~mm} \\
\text { depending on } \\
\text { detector size }\end{array}$ & $\begin{array}{c}<0.1 \mathrm{~mm} \text { depending on camera } \\
\text { matrix }\end{array}$ \\
\hline $\begin{array}{l}\text { Penetration } \\
\text { depth }\end{array}$ & $\begin{array}{l}1 \text { to } 30 \mathrm{~cm} \text { depending on } \\
\text { US frequency, US probe } \\
\text { can be inserted into } \\
\text { gastrointestinal tract }\end{array}$ & Limitless & Limitless & Limitless & Limitless & Superficial \\
\hline $\begin{array}{l}\text { Soft tissue } \\
\text { contrast }\end{array}$ & Good & Medium & Excellent & NA & NA & Visual contrast \\
\hline $\begin{array}{l}\text { Vascular } \\
\text { imaging } \\
\text {-Anatomy of } \\
\text { vessels }(\mathrm{AV})\end{array}$ & $\begin{array}{l}\text { AV: 2D, angiography, } \\
\text { venography. HD: blood } \\
\text { flow, blood volume, } \\
\text { velocity, }\end{array}$ & $\begin{array}{l}\text { AV: 2D and 3D } \\
\text { angiography, } \\
\text { venography. HD: } \\
\text { blood flow, blood } \\
\text { volume, velocity, }\end{array}$ & $\begin{array}{l}\text { AV: 2D and 3D, angiography, } \\
\text { venography. HD: blood flow, } \\
\text { blood volume, velocity, perfusion. } \\
\text { CA injection not necessary }\end{array}$ & HD : blood flow & HD: blood flow & $\begin{array}{l}\text { AV: limited to superficial } \\
\text { mucosal vessels, improved with } \\
\text { narrow band imaging (higher } \\
\text { relative intensity of blue light) }\end{array}$ \\
\hline
\end{tabular}




\begin{tabular}{|c|c|c|c|c|c|c|}
\hline $\begin{array}{l}\text {-Hemodynamics } \\
\text { (HD) }\end{array}$ & $\begin{array}{c}\text { using Color encoded } \\
\text { Doppler, Power Doppler } \\
\text { (B-flow) or CEUS }\end{array}$ & $\begin{array}{l}\text { arterial, venous and } \\
\text { perfusion phases, } \\
\text { using CA injection }\end{array}$ & & & & \\
\hline $\begin{array}{l}\text { Organ } \\
\text { volumetry }\end{array}$ & $\begin{array}{l}\text { Multiplanar 2D imaging, } \\
\text { volumetric analysis with } \\
\text { 3D option }\end{array}$ & $\begin{array}{l}\text { Axial 2D and 3D } \\
\text { imaging }\end{array}$ & Multiplanar 2D and 3D imaging & 2D and 3D imaging & $\begin{array}{l}\text { 3D but requires CT } \\
\text { or MRI for } \\
\text { anatomical location }\end{array}$ & $\begin{array}{l}\text { Size estimation from organ } \\
\text { surface view (images, videos) }\end{array}$ \\
\hline $\begin{array}{l}\text { Fibrosis } \\
\text { assessment }\end{array}$ & $\begin{array}{c}\text { Organ surface } \\
\text { morphology, parenchymal } \\
\text { echogenicity, elastometry } \\
\text { or elastography }\end{array}$ & $\begin{array}{l}\text { Morphology, } \\
\text { texture analysis }\end{array}$ & $\begin{array}{l}\text { Morphology, texture analysis, } \\
\text { hepatocyte specificCA, } \\
\text { relaxometry, diffusion MRI, } \\
\text { elastography, }{ }^{31} \mathrm{P}-\mathrm{MRS}\end{array}$ & $\begin{array}{c}{ }^{99 \mathrm{~m}} \mathrm{Tc}-\text { labelled sulphur } \\
\text { colloid particles }\end{array}$ & ${ }^{18} \mathrm{~F}$ fluorocholine & Organ surface morphology \\
\hline $\begin{array}{l}\text { Detection of } \\
\text { splenic siderotic } \\
\text { nodules }\end{array}$ & $\begin{array}{l}\text { Hyperechogenic } \\
\text { parenchymal foci, } \\
\text { acoustic shadowing if } \\
\text { calcified }\end{array}$ & $\begin{array}{l}\text { Attenuation } \\
\text { dependent on } \\
\text { calcification, } \\
\text { hypodense on } \\
\text { contrast enhanced } \\
\text { CT }\end{array}$ & $\begin{array}{l}\text { Hypointense lesion on } \mathrm{T}_{1} \mathrm{~W} \text { MRI, } \\
\mathrm{T}_{2} \mathrm{~W} \text { MRI, SWI, even after CA } \\
\text { administration }\end{array}$ & No & No & No \\
\hline $\begin{array}{l}\text { Theranostic } \\
\text { applications }\end{array}$ & $\begin{array}{l}\text { Use of high intensity } \\
\text { focussed ultrasounds } \\
\text { (HiFu) for abdominal } \\
\text { cancer treatment }\end{array}$ & $\begin{array}{l}\text { (Preclinical } \\
\text { research) }\end{array}$ & (Preclinical research) & $\begin{array}{l}\text { Yttrium for liver } \\
\text { cancers }\end{array}$ & $\begin{array}{l}\text { (Preclinical and } \\
\text { clinical research) }\end{array}$ & $\begin{array}{l}\text { Theranostic capsule endoscopy } \\
\text { (research) } \\
\text { Fluorescence imaging endoscopy } \\
\text { with nanoparticles (research) }\end{array}$ \\
\hline
\end{tabular}




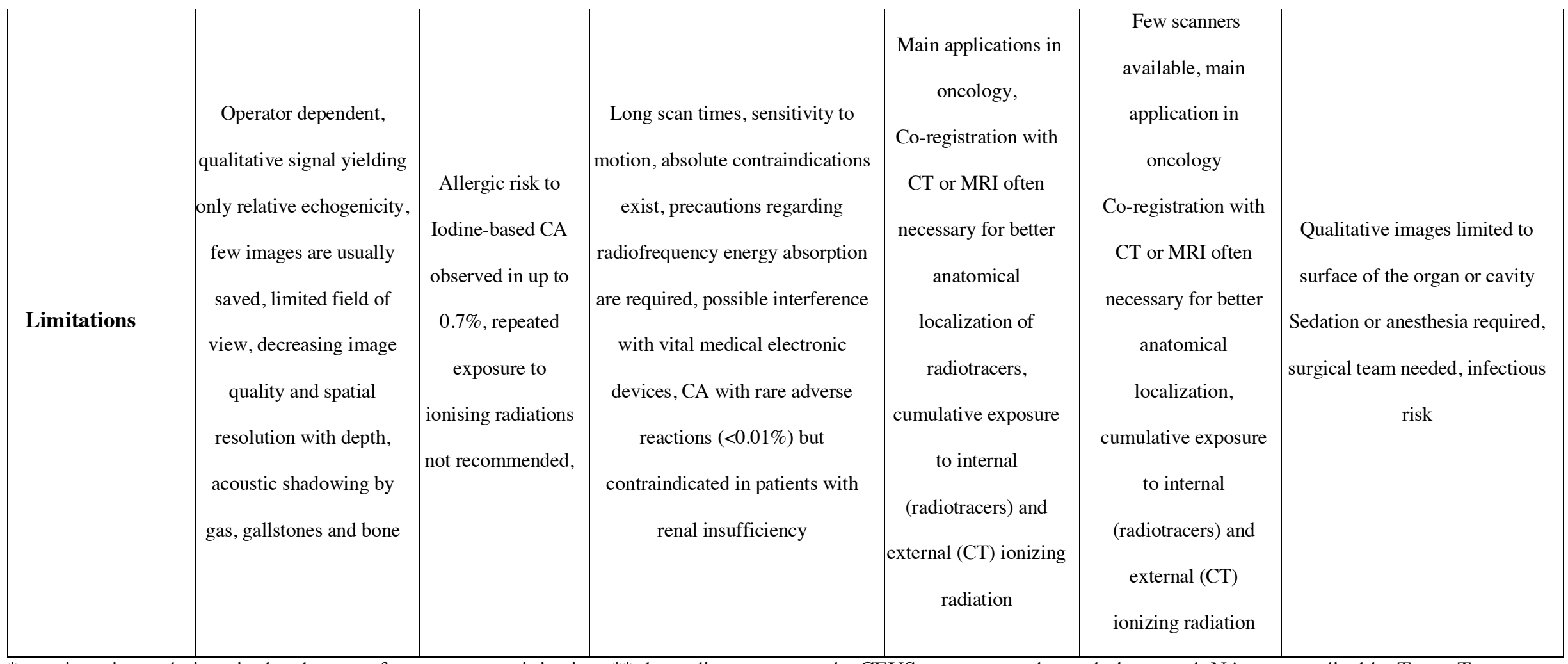

$*$ non-invasive technique in the absence of contrast agent injection; $* *$ depending on protocols; $\mathrm{CEUS}=$ contrast enhanced ultrasound; $\mathrm{NA}=$ not applicable; $\mathrm{T}_{1} \mathrm{~W}=\mathrm{T}_{1}-$

weighted MRI; $\mathrm{T}_{2} \mathrm{~W}=\mathrm{T}_{2}$-weighted MRI, US = ultrasound. 
Table 2. Assessment of human HSS morbidity with abdominal imaging modalities

\begin{tabular}{|c|c|c|c|c|c|c|c|}
\hline $\begin{array}{l}\text { Imaging findings in } \\
\text { hepatosplenic } \\
\text { schistosomiasis }\end{array}$ & $\begin{array}{l}\text { Disease } \\
\text { stage }\end{array}$ & USG & CT & MRI & $\begin{array}{c}\text { Scintigraphy / } \\
\text { SPECT }\end{array}$ & PET & Endoscopy \\
\hline $\begin{array}{l}\text { Schistosome } \\
\text { visualisation }\end{array}$ & $\begin{array}{l}\text { Acute stage } \\
\text { Chronic stage }\end{array}$ & $\begin{array}{c}\text { In combination with } \\
\text { endoscopy }\end{array}$ & No & No & No & No & No \\
\hline $\begin{array}{l}\text { Granulomatous } \\
\text { inflammation }\end{array}$ & Chronic stage & $\begin{array}{c}\text { Yes } \\
\text { Echogenic structure }\end{array}$ & With and without CA & Anatomical MRI & Yes & ${ }^{18} \mathrm{FDG}$ & Yes (laparoscopy) \\
\hline $\begin{array}{l}\text { Liver fibrosis } \\
\text { (Symmers pipestem } \\
\text { fibrosis) }\end{array}$ & Chronic stage & $\begin{array}{l}\text { Yes, standard patterns, } \\
\text { measurement of portal vein, } \\
\text { gall bladder and fibrosis of } \\
\text { second order branches }\end{array}$ & $\begin{array}{l}\text { Measurement of portal vein, } \\
\text { gall bladder and fibrosis of } \\
\text { portal vein branches }\end{array}$ & $\begin{array}{l}\text { Measurement of portal } \\
\text { vein, gall bladder and } \\
\text { fibrosis of portal vein } \\
\text { branches }\end{array}$ & No & No & $\begin{array}{l}\text { In advanced stage fibrosis } \\
\text { visible at the liver surface by } \\
\text { laparoscopy }\end{array}$ \\
\hline Portal hypertension & Chronic stage & $\begin{array}{l}\text { Portal vein diameter, blood } \\
\text { flow and velocity Doppler } \\
\text { USG }\end{array}$ & $\begin{array}{l}\text { Portal phase after CA } \\
\text { injection, } \\
\text { detection of vessel dilation }\end{array}$ & Anatomical MRI & $\begin{array}{l}\text { hepatic } \\
\text { angioscintigraphy with } \\
99 \text { mTc-labelled sulphur } \\
\text { colloid particles }\end{array}$ & No & $\begin{array}{l}\text { Yes, qualitative } \\
\text { (laparoscopy) }\end{array}$ \\
\hline
\end{tabular}




\begin{tabular}{|c|c|c|c|c|c|c|c|}
\hline Hepatomegaly & $\begin{array}{l}\text { Acute stage } \\
\text { Chronic stage }\end{array}$ & $\begin{array}{l}\text { Qualitative evaluation and } \\
\text { organ axis measurements, no } \\
\text { volumetric analysis without } \\
\text { 3D option }\end{array}$ & Yes, volumetric analysis & Yes, volumetric analysis & Qualitative & No & $\begin{array}{l}\text { Yes, qualitative } \\
\text { (laparoscopy) }\end{array}$ \\
\hline Splenomegaly & $\begin{array}{l}\text { Acute stage } \\
\text { Chronic stage } \\
\text { (severe HSS) }\end{array}$ & $\begin{array}{l}\text { Qualitative evaluation and } \\
\qquad \text { organ main axis } \\
\text { measurement, no volumetric } \\
\text { analysis without 3D option }\end{array}$ & Yes, volumetric analysis & Yes, volumetric analysis & $\begin{array}{c}\text { Yes, volumetric } \\
\text { analysis }\end{array}$ & No & $\begin{array}{l}\text { Yes, qualitative } \\
\text { (laparoscopy) }\end{array}$ \\
\hline $\begin{array}{l}\text { Gall bladder } \\
\text { abnormalities }\end{array}$ & Chronic stage & $\begin{array}{l}\text { Yes, wall thickness } \\
\text { measurement }\end{array}$ & $\begin{array}{l}\text { Yes, wall thickening and } \\
\text { inflammation visible }\end{array}$ & $\begin{array}{l}\text { Yes, wall thickening and } \\
\text { inflammation visible }\end{array}$ & No & No & $\begin{array}{l}\text { Yes, if reaching the gall } \\
\text { bladder surface }\end{array}$ \\
\hline Esophageal varices & $\begin{array}{l}\text { Chronic stage } \\
\text { (severe HSS) }\end{array}$ & Yes with special probe & Yes, venography & Yes, venography & No & No & Yes, gold standard \\
\hline Visceral collaterals & $\begin{array}{l}\text { Chronic stage } \\
\text { (severe HSS) }\end{array}$ & $\begin{array}{c}\text { USG angiography, Doppler } \\
\text { USG }\end{array}$ & Angiography with CA & Angiography & No & No & $\begin{array}{l}\text { Yes, qualitative } \\
\text { (laparoscopy) }\end{array}$ \\
\hline $\begin{array}{l}\text { Splenic siderotic } \\
\text { nodules }\end{array}$ & Chronic stage & $\begin{array}{l}\text { Hyperechogenic parenchymal } \\
\text { foci, acoustic shadowing if } \\
\text { calcified }\end{array}$ & $\begin{array}{l}\text { Attenuation dependent on } \\
\text { calcification, hypodense on } \\
\text { contrast enhanced CT }\end{array}$ & $\begin{array}{l}\text { Hypointense lesion on } \mathrm{T}_{1}-\mathrm{w} \\
\text { MRI, } \mathrm{T}_{2} \text {-w MRI, SWI, even } \\
\text { after CA administration }\end{array}$ & No & No & No \\
\hline Ascites & $\begin{array}{l}\text { Chronic stage } \\
\text { (severe HSS) }\end{array}$ & Anechoic fluid & $\begin{array}{c}\text { Hypodense with respect to } \\
\text { liver parenchyma }\end{array}$ & Anatomical MRI & No & No & $\begin{array}{c}\text { Yes, qualitative } \\
\text { (laparoscopy) }\end{array}$ \\
\hline
\end{tabular}


$\mathrm{CT}=$ computed tomography; $\mathrm{MRI}=$ magnetic resonance imaging; $\mathrm{PET}=$ positron emission tomography; $\mathrm{SPECT}=\mathrm{Single}-\mathrm{photon}_{\mathrm{emission}}$ computed tomography; $\mathrm{T}_{1} \mathrm{~W}=\mathrm{T}_{1}{ }^{-}$ weighted MRI; $\mathrm{T}_{2} \mathrm{~W}=\mathrm{T}_{2}$-weighted MRI; USG = Ultrasonography 
Table 3. Assessment of liver fibrosis in HSS with elastography ${ }^{1}$

\begin{tabular}{|c|c|c|c|c|c|c|c|}
\hline References & Comorbidities & Parasite strain & Population characteristics & Elastographic method & $\begin{array}{c}\text { Additional } \\
\text { Imaging } \\
\text { modalitie(s) }\end{array}$ & Main findings & Limitations \\
\hline [40] & None & S.mansoni & $\begin{array}{l}\text {-358 Brazilian patients, among them } \\
86 \text { with mild periportal fibrosis } \\
\text { (Niamey C pattern) and } 272 \text { with } \\
\text { advanced periportal fibrosis } \\
\text { (Niamey D, E, F patterns) }\end{array}$ & $\begin{array}{l}\text { Point shear wave } \\
\text { elastography, ARFI }\end{array}$ & $\begin{array}{l}\text { USG with a 6C1 } \\
\text { MHz transducer } \\
\text { for USG and } \\
\text { elastography }\end{array}$ & $\begin{array}{c}\text { Differentiation } \\
\text { between mild and } \\
\text { advanced periportal } \\
\text { fibrosis }\end{array}$ & $\begin{array}{c}\text { USG and } \\
\text { elastography } \\
\text { performed by the } \\
\text { same sonographer }\end{array}$ \\
\hline [42] & None & S. japonicum & $\begin{array}{l}\text {-106 Chinese patients with } \\
\text { advanced schistosomiasis and no } \\
\text { current infection, among them } 80 \\
\text { patients without comorbidities } \\
\text { (blood tests with biochemical } \\
\text { assessment of liver function and } \\
\text { fibrosis, percutaneous liver biopsy) } \\
\text {-Conclusive results obtained on } 73 \\
\text { patients (METAVIR score: } 3 \text { F0, } 11 \\
\text { F1, 22 F2, 24 F3, 13 F4) }\end{array}$ & $\begin{array}{l}\text { Transient elastography, } \\
\text { FibroScan }\end{array}$ & $\begin{array}{l}\text { USG } \\
\text { classification } \\
\text { into } 5 \text { grades, } \\
\text { Doppler USG, } \\
\text { histology }\end{array}$ & $\begin{array}{l}\text {-No correlation } \\
\text { between LSM and } \\
\text { USG grading but good } \\
\text { correlation with } \\
\text { histology } \\
\text {-LSM superior to } \\
\text { blood serum analysis } \\
\text { for detection of } \\
\text { fibrosis and cirrhosis } \\
\text { and predictive of } \\
\text { fibrosis in patients }\end{array}$ & $\begin{array}{l}\text { No USG-based } \\
\text { classification of } \\
\text { liver fibrosis } \\
\text { (Niamey patterns) }\end{array}$ \\
\hline
\end{tabular}




\begin{tabular}{|c|c|c|c|c|c|c|c|}
\hline & & & & & & $\begin{array}{l}\text { with advanced } \\
\text { schistosomiasis } \\
\text { japonica }\end{array}$ & \\
\hline [41] & None & S.mansoni & $\begin{array}{l}-77 \text { Brazilian patients: } 30 \text { with } \\
\text { hepatosplenic schistosomiasis ( } 24 \% \\
\text { Niamey B pattern, } \\
28 \% \text { Niamey C pattern, } 48 \% \\
\text { Niamey D pattern), } 30 \text { patients with } \\
\text { HCV cirrhosis and } 17 \text { controls }\end{array}$ & $\begin{array}{c}\text { Transient elastography, } \\
\text { FibroScan }\end{array}$ & $\begin{array}{c}\text { USG with } \\
\text { Doppler- } \\
\text { fluxometry, } \\
\text { ultrasound color } \\
\text { Doppler }\end{array}$ & $\begin{array}{c}\text { - Increased LSM } \\
\text { values in patients with } \\
\text { schistosomiasis } \\
\text { compared to controls } \\
\text {-Increased spleen } \\
\text { stiffness, comparable } \\
\text { to that of cirrhotics } \\
\text {-increased spleen } \\
\text { stiffness correlated } \\
\text { with portal } \\
\text { hypertension }\end{array}$ & $\begin{array}{l}\text { - Absence of severe } \\
\text { fibrosis (e.g. } \\
\text { patterns E or F) } \\
\text { - differentiation of } \\
\text { schistosomiasis } \\
\text { patients from } \\
\text { cirrhotic patients } \\
\text { by LSM could be } \\
\text { biased }\end{array}$ \\
\hline [39] & $\mathrm{HCV}$ & $\begin{array}{l}\text { Unknown, } S \text {. } \\
\text { mansoni most } \\
\text { likely }\end{array}$ & $\begin{array}{l}\text {-352 Egyptian patients with chronic } \\
\text { HCV hepatitis (no decompensated } \\
\text { cirrhosis, no HCC): } 122 \text { controls, } \\
122 \text { with positive antischistosomal } \\
\text { antibodies and } \\
\text { without periportal tract thickening, }\end{array}$ & $\begin{array}{c}\text { Transient elastography, } \\
\text { FibroScan }\end{array}$ & USG & $\begin{array}{c}\text {-No difference in liver } \\
\text { stiffness among } \\
\text { groups } \\
\text {-Best correlation } \\
\text { between METAVIR } \\
\text { score and LSM in }\end{array}$ & $\begin{array}{l}\text { No USG-based } \\
\text { classification of } \\
\text { liver fibrosis } \\
\text { (Niamey patterns) }\end{array}$ \\
\hline
\end{tabular}




\begin{tabular}{|c|c|c|c|c|c|c|c|}
\hline & & & $\begin{array}{l}108 \text { with positive antischistosomal } \\
\text { antibodies and } \\
\text { periportal tract thickening } \\
\text {-Liver biopsies and METAVIR } \\
\text { scores available }\end{array}$ & & & $\begin{array}{l}\text { patients with HCV } \\
\text { only } \\
\text {-Only higher } \\
\text { antischistosomal } \\
\text { antibody titres reduce } \\
\text { the correlation } \\
\text { between METAVIR } \\
\text { score and LSM }\end{array}$ & \\
\hline [98] & $\mathrm{HCV}$ & $\begin{array}{l}\text { Unknown, } S \text {. } \\
\text { mansoni most } \\
\text { likely }\end{array}$ & $\begin{array}{l}\text {-312 Egyptian patients with HCV } \\
\text { genotype 4, among them } 36 \text { with } \\
\text { positive schistosomiasis serology, } \\
\text { and } 4 \text { with hepatic schistosomiasis } \\
\text { lesions detected on liver biopsy }\end{array}$ & $\begin{array}{l}\text { Transient elastography, } \\
\text { FibroScan }\end{array}$ & No & $\begin{array}{l}\text { No influence of } \\
\text { positive } \\
\text { schistosomiasis } \\
\text { serology on } \\
\text { elastography results }\end{array}$ & $\begin{array}{l}\text { Very small number } \\
\text { of patients with } \\
\text { schistosomiasis } \\
\text { lesions }\end{array}$ \\
\hline [38] & $\mathrm{HCV}$ & $\begin{array}{l}\text { Unknown, } S \text {. } \\
\text { mansoni most } \\
\text { likely }\end{array}$ & $\begin{array}{l}\text {-231 Egyptian patients with chronic } \\
\mathrm{HCV} \text {, among them } 67 \text { patients } \\
\text { presenting positive schistosomal } \\
\text { serology } \\
\text {-Liver biopsies and METAVIR } \\
\text { scores: } 31 \text { F0-F1, 13 F2, 14 F3 and } 9 \\
\text { F4 }\end{array}$ & $\begin{array}{c}\text { Transient elastography, } \\
\text { FibroScan }\end{array}$ & No & $\begin{array}{l}\text { Positive schistosomal } \\
\text { serology impairs } \\
\text { correlation between } \\
\text { FibroScan results and } \\
\text { METAVIR score } \\
\text { (more obvious in F2 } \\
\text { and F3 stages) }\end{array}$ & $\begin{array}{l}\text { No USG-based } \\
\text { classification of } \\
\text { liver fibrosis } \\
\text { (Niamey patterns) }\end{array}$ \\
\hline
\end{tabular}


*Transient elastography and Point shear wave elastography are strictly speaking no imaging modalities since LSM is performed in a point at a particular depth. Transient elastography uses a one-dimensional USG signal for guidance, while Point shear wave elastography relies on 2D USG for determining the measurement point. ARFI = acoustic radiation force imaging; $\mathrm{HCV}=$ Hepatitis $\mathrm{C}$ virus; $\mathrm{HCC}=$ hepatocellular carcinoma; LSM= Liver Stiffness Measurement; USG = Ultrasonography . 
Table 4. Preclinical imaging studies of schistosomiasis

\begin{tabular}{|c|c|c|c|c|c|c|c|}
\hline References & $\begin{array}{c}\text { Imaging modalities } \\
\text { and methods }\end{array}$ & $\begin{array}{c}\text { Animal model and } \\
\text { groups }\end{array}$ & $\begin{array}{l}\text { Parasite, number } \\
\text { of cercariae and } \\
\text { mode of infection }\end{array}$ & $\begin{array}{c}\text { Observation } \\
\text { period }\end{array}$ & $\begin{array}{l}\text { Assessment of } \\
\text { pathogenic } \\
\text { features }\end{array}$ & Main findings & $\begin{array}{c}\text { Potential } \\
\text { applications }\end{array}$ \\
\hline [91] & $\begin{array}{l}\text { BLI, endogenous } \\
\text { expression of luciferase } \\
\text { under a collagen promotor }\end{array}$ & $\begin{array}{l}\text { Male and female B6.Coll } \\
\text { 1A-luc+ mice (C57BL6/J } \\
\text { background) } \\
\text { SjC mice (n=12), SjP mice } \\
\quad(\mathrm{n}=14) \\
\text { SjC mice treated with PZQ } \\
(\mathrm{n}=10), \text { SjP mice treated } \\
\text { with PZQ (n=10) } \\
\text { Control group }(\mathrm{n}=5)\end{array}$ & $\begin{array}{c}\text { S. japonicum (SjC, } \\
\text { Chinese origin, } 35 \\
\text { cercariae) and } S j P \\
\text { (Philippines origin, } 14 \\
\text { cercariae) }\end{array}$ & $\begin{array}{l}\text { From week } 4 \text { to } \\
10 \text { post infection } \\
\text { for } \mathrm{SjC} \text { mice, and } \\
\text { from week } 4 \text { to } 11 \\
\text { post infection for } \\
\mathrm{SjP}\end{array}$ & $\begin{array}{l}\text {-Collagen deposition } \\
\text { with BLI and } \\
\text { comparison with } \\
\text { histology }\end{array}$ & $\begin{array}{l}\text {-Dynamic assessment } \\
\text { of collagen deposition } \\
\text { before and after PZQ } \\
\text { treatment }\end{array}$ & $\begin{array}{l}\text {-Assessment of } \\
\text { antifibrotic drug } \\
\text { effects in infected } \\
\text { mice }\end{array}$ \\
\hline [92] & $\begin{array}{l}\text { USG, classic (18-4 MHz } \\
\text { human probe) and high- } \\
\text { resolution (50 MHz probe, } \\
\text { resolution } 30 \mu \mathrm{m})\end{array}$ & $\begin{array}{l}\text { 5-week old infected } \\
\text { BALB/C female mice } \\
(\mathrm{n}=22) \text { and controls } \\
\text { (number unknown) }\end{array}$ & $\begin{array}{c}\text { S. japonicum } \\
\text { (Yamanashi strain), } 25 \\
\text { cercariae }(\mathrm{n}=12) \text { and } \\
10 \text { cercariae }(\mathrm{n}=10), \\
\text { percutaneous route }\end{array}$ & $\begin{array}{l}\text { Up to } 13 \text { weeks } \\
(\mathrm{n}=12) \text { and one } \\
\text { year }(\mathrm{n}=10) \text { post } \\
\text { infection }\end{array}$ & $\begin{array}{l}\text {-Morphometry of } \\
\text { spleen and liver, signs } \\
\text { of PH, } \\
\text { intestinal wall } \\
\text { thickening, }\end{array}$ & $\begin{array}{l}\text {-Visualisation of live } \\
\text { worms in portal vein } \\
\text {-Real-time evaluation } \\
\text { of schistosomiasis } \\
\text { impact on digestive } \\
\text { organs }\end{array}$ & $\begin{array}{c}\text {-Studies of new } \\
\text { anti-parasitic drugs } \\
\text { on worms, } \\
\text { longitudinal } \\
\text { preclinical studies } \\
\text { (therapy, molecular }\end{array}$ \\
\hline
\end{tabular}




\begin{tabular}{|c|c|c|c|c|c|c|c|}
\hline & & & & & $\begin{array}{c}\text { echogenic patterns of } \\
\text { liver fibrosis }\end{array}$ & & $\begin{array}{l}\text { mechanisms of } \\
\text { disease, transfer to } \\
\text { the clinical setting) }\end{array}$ \\
\hline [95] & $\begin{array}{c}\text { MRI @ 11.75T,2D } \\
\text { anatomical MRI with and } \\
\text { without Gd-DOTA } \\
\text { injection } \\
\text { Relaxometric studies ( } \mathrm{T}_{2} \\
\text { mapping, } \mathrm{T}_{2} * \text { mapping) } \\
\text { comparison with histology }\end{array}$ & $\begin{array}{c}\text { 6-week old CBA/J female } \\
\text { mice, infested mice }(n=12) \\
\text { and controls }(n=12)\end{array}$ & $\begin{array}{c}\text { S. mansoni, } \\
30 \text { cercariae, } \\
\text { percutaneous route }\end{array}$ & $\begin{array}{c}2,6 \text { and } 10 \text { weeks } \\
\text { post infection }\end{array}$ & $\begin{array}{l}\text {-Liver and spleen } \\
\text { volumetry, and PH } \\
\text { assessment with } \\
\text { anatomical MRI } \\
\text {-Fibrosis assessment } \\
\text { with relaxometry and } \\
\text { histology }\end{array}$ & $\begin{array}{c}\text {-Detection of indirect } \\
\text { signs of } \mathrm{PH} \\
\text {-Quantification of } \\
\text { splenomegaly and } \\
\text { hepatomegaly } \\
\text {-Identification of } \mathrm{T}_{2} \\
\text { relaxation time as a } \\
\text { marker for liver } \\
\text { fibrosis }\end{array}$ & $\begin{array}{l}\text {-Longitudinal } \\
\text { studies of } \\
\text { antifibrotic drug } \\
\text { effects, mechanistic } \\
\text { studies on genes or } \\
\text { immune molecules } \\
\text { involved in } \\
\text { fibrogenesis } \\
\text {-Transfer to the } \\
\text { clinical setting }\end{array}$ \\
\hline [93] & $\begin{array}{c}\text { MicroSPECT/CT } \\
\text { with injection of 188Re- } \\
\text { OCTAM }\end{array}$ & $\begin{array}{l}6 \text { to } 8 \text {-week old BALB/C } \\
\text { male mice, divided in } 3 \\
\text { groups of infected mice and } \\
\text { one control group ( } \mathrm{n}=7-10 \\
\text { per group) }\end{array}$ & $\begin{array}{l}\text { S. mansoni (Puerto } \\
\text { Rican strain), } 100 \\
\text { cercariae, } \\
\text { percutaneous route }\end{array}$ & $\begin{array}{l}\text { Imaging at } 1,4, \\
24 \text { and } 48 \mathrm{~h} \text { post } \\
\text { injection of } \\
\text { 188Re-OCTAM, } \\
9,12 \text { and } 18 \\
\text { weeks post } \\
\text { infection }\end{array}$ & $\begin{array}{l}\text {-Liver inflammation, } \\
\text { necrosis and fibrosis }\end{array}$ & $\begin{array}{c}\text {-Identification of } \\
\text { various levels of } \\
\text { remnant liver function } \\
\text { in different stages of } \\
\text { the disease }\end{array}$ & $\begin{array}{c}\text {-Longitudinal } \\
\text { studies of } \\
\text { antifibrotic drug } \\
\text { effects, mechanistic } \\
\text { studies on genes or } \\
\text { immune molecules } \\
\text { involved in } \\
\text { fibrogenesis }\end{array}$ \\
\hline
\end{tabular}




\begin{tabular}{|c|c|c|c|c|c|c|c|}
\hline [85] & $\begin{array}{l}\text { micoPET using }{ }^{18} \mathrm{FDG}+ \\
\text { FMT with near-infrared } \\
\quad \text { imaging agent } \\
\text { MRI @7T for } \mathrm{T}_{2} \text {-weighted } \\
\text { images with contrast agent, } \\
\text { comparison with histology }\end{array}$ & $\begin{array}{l}\text { 6-week old female nude } \\
\text { mice }(\mathrm{nu} / \mathrm{nu}) \\
\text { Infected mice }(\mathrm{n}=35) \text { and } \\
\text { controls }(\mathrm{n}=4), 6 \text { mice } \\
\text { treated with PZQ }\end{array}$ & $\begin{array}{l}\text { S. mansoni, number of } \\
\text { cercariae unknown, } \\
\text { percutaneous route }\end{array}$ & $\begin{array}{c}\text { 5-6 weeks post } \\
\text { infection }\end{array}$ & $\begin{array}{l}\text {-Localization and } \\
\text { quantification of } \\
\text { schistosome worms }\end{array}$ & $\begin{array}{l}{ }^{-18} \text { FDG fixed by } S \\
\text { mansoni } \text { worms } \\
\text {-In vivo quantification } \\
\text { of the worm burden } \\
\text { with }{ }^{18} \text { FDG PET }\end{array}$ & $\begin{array}{l}\text {-Studies of new } \\
\text { anti-parasitic drug } \\
\text { effects on worms } \\
\text {-In vivo parasite } \\
\text { detection in humans }\end{array}$ \\
\hline [84] & $\begin{array}{c}\text { FMT with near-infrared } \\
\text { imaging agent }\end{array}$ & $\begin{array}{l}6 \text { to } 8 \text {-week old female } \\
\text { BALB/c mice (exact } \\
\text { number unknown) }\end{array}$ & $\begin{array}{l}\text { S. mansoni (Puerto } \\
\text { Rican strain), } 100 \text { or } \\
50 \text { cercariae per } \\
\text { mouse, S. hematobium, } \\
25 \text { cercariae per mouse } \\
\text { and } \text { S. Japonicum, } 25 \\
\text { cercariae per mouse, } \\
\text { percutaneous route }\end{array}$ & $\begin{array}{c}5 \text { weeks ( } S . \\
\text { Mansoni), } 8 \\
\text { weeks ( } S . \\
\text { Hematobium) and } \\
6 \text { weeks ( } S . \\
\text { Japonicum) post } \\
\text { infection }\end{array}$ & $\begin{array}{l}\text {-Localization and } \\
\text { quantification of } \\
\text { schistosome worms }\end{array}$ & $\begin{array}{l}\text {-New method to } \\
\text { detect, quantify and } \\
\text { localize worms }\end{array}$ & $\begin{array}{l}\text {-Studies of new } \\
\text { anti-parasitic drug } \\
\text { effects on worms }\end{array}$ \\
\hline [90] & $\begin{array}{l}\text { BLI, genetically encoded } \\
\text { luciferase (luc) reporter } \\
\text { driven by an eosinophil } \\
\text { peroxidase (EPX) } \\
\text { promoter, intraperitoneal } \\
\text { injection of luciferase } \\
\text { substrate luciferin }\end{array}$ & $\begin{array}{l}\text { EPX334-luc or EPX339- } \\
\text { luc mice and EPX-luc } \\
\text { hemizygous mice as } \\
\text { controls (age and exact } \\
\text { number unknown) }\end{array}$ & $\begin{array}{c}\text { S. mansoni, } 50 \\
\text { cercariae, } \\
\text { subcutaneous route }\end{array}$ & $\begin{array}{l}\text { Over 12-week } \\
\text { period post } \\
\text { infection }\end{array}$ & $\begin{array}{c}\text {-Eosinophilia and } \\
\text { eosinopoiesis }\end{array}$ & $\begin{array}{l}\text {-Detection and } \\
\text { quantification of } \\
\text { eosinophilia and } \\
\text { eosinopoiesis in } \\
\text { schistosomiasis } \\
\text {-First in vivo } \\
\text { description of }\end{array}$ & $\begin{array}{c}\text {-Study of molecules } \\
\text { modulating } \\
\text { eosinophilia and } \\
\text { eosinopoiesis in } \\
\text { schistosomiasis }\end{array}$ \\
\hline
\end{tabular}




\begin{tabular}{|c|c|c|c|c|c|c|c|}
\hline & & & & & & $\begin{array}{l}\text { eosinopoietic } \\
\text { response to } \\
\text { schistosomes }\end{array}$ & \\
\hline [94] & $\begin{array}{c}\text { MRI @9.4T, anatomical } \\
\mathrm{T}_{1}, \mathrm{~T}_{2}, \mathrm{~T}_{2}{ }^{*} \text {-weighted MRI, } \\
\text { no contrast agent }\end{array}$ & $\begin{array}{l}10 \text { to } 20 \text {-week old BALB/C } \\
\text { infected mice and controls } \\
\text { (exact number unknown) }\end{array}$ & $\begin{array}{c}\text { S. mansoni, } 150 \\
\text { cercariae, } \\
\text { subcutaneous route }\end{array}$ & $\begin{array}{l}\text { Followed for } 13 \\
\text { weeks post } \\
\text { infection }\end{array}$ & $\begin{array}{l}\text {-Assessment of liver } \\
\text { disease and } \\
\text { involvement of } \\
\text { intrahepatic bile ducts }\end{array}$ & $\begin{array}{l}\text {-Patchy pattern in the } \\
\text { liver related to } \\
\text { fibrosis after } 6 \text { weeks } \\
\text { of infection }\end{array}$ & $\begin{array}{l}\text {-Anatomical MRI } \\
\text { for the assessment } \\
\text { of liver disease in } \\
\text { preclinical studies }\end{array}$ \\
\hline [99] & $\begin{array}{l}\text { USG with a } \\
\text { system for human imaging } \\
\text { (multifrequent convex } \\
\text { array probe of } 3.5 / 4.3 / 5.0 \\
\mathrm{MHz} \text { ) }\end{array}$ & $\begin{array}{l}\text { 12-week old female and } \\
\text { castrated male pigs (Danish } \\
\text { landrace x Duroc and or } \\
\text { Hampshire crossbreeds) } \\
\text { Infected pigs ( } n=9) \text { and } \\
\text { uninfected controls }(n=10)\end{array}$ & $\begin{array}{l}\text { S. japonicum, } 1000 \\
\text { cercariae of Chinese } \\
\text { origin. } \\
\text { Route of injection not } \\
\text { documented. }\end{array}$ & $\begin{array}{l}\text { Imaged } 12 \text { weeks } \\
\text { after infection }\end{array}$ & $\begin{array}{l}\text {-Assessment of HSS } \\
\text { disease, comparison } \\
\text { of USG findings with } \\
\text { histology }\end{array}$ & $\begin{array}{l}\text {-Enlarged liver } \\
\text { Diffuse parenchymal } \\
\text { alterations } \\
\text {-Echogenic portal } \\
\text { thickening } \\
\text {-Enlarged portal vein } \\
\text { diameter }\end{array}$ & $\begin{array}{l}\text {-Validation of the } \\
\text { swine model of } \\
\text { schistosomiasis as a } \\
\text { good model of } \\
\text { human HSS }\end{array}$ \\
\hline [100] & Portable USG & $\begin{array}{c}\text { 8 semi-captive } \\
\text { chimpanzees (Uganda), } \\
\text { infected by S. mansoni, } \\
\text { under PZQ treatment but } \\
\text { still excreting schistosome } \\
\text { eggs }\end{array}$ & $\begin{array}{l}\text { S. mansoni (naturally } \\
\text { infected animals) }\end{array}$ & $\begin{array}{l}\text { USG included in } \\
\text { the annual health } \\
\text { assessment of } \\
\text { infected animals }\end{array}$ & $\begin{array}{l}\text {-Assessment of } \\
\text { intestinal disease and } \\
\text { progression toward } \\
\text { HSS. } \\
\text {-Parasitological } \\
\text { assessment (urine and } \\
\text { stools) }\end{array}$ & $\begin{array}{c}\text {-Detection of a } \\
\text { spectrum of fibrosis } \\
\text { stages including mild } \\
\text { disease, pipestem } \\
\text { fibrosis and occluding } \\
\text { fibrosis. }\end{array}$ & $\begin{array}{l}\text {-Detection of } \\
\text { fibrosis patterns } \\
\text { identical to those } \\
\text { described in humans } \\
\text { (Niamey protocol) }\end{array}$ \\
\hline
\end{tabular}




\begin{tabular}{|c|c|c|c|c|c|c|c|}
\hline & & & & & $\begin{array}{l}\text {-DNA schistosome } \\
\text { barcoding }\end{array}$ & $\begin{array}{c}\text {-DNA schistosome } \\
\text { diversity }\end{array}$ & $\begin{array}{l}\text { Probable zoonosis } \\
\text { (chimpanzees, } \\
\text { humans, snails) }\end{array}$ \\
\hline [101] & USG ( $\mathrm{B}$ mode) & $\begin{array}{l}24 \text { male New-Zealand } \\
\text { rabbits infected with } S \text {. } \\
\text { japonicum used for the } \\
\text { assessment of the anti- } \\
\text { fibrotic effects of Chinese } \\
\text { traditional medicine } \\
-6 \text { animals received PZQ } \\
-6 \text { animals received Radix } \\
\text { astragali and Salvia } \\
\text { miltiorrhiza } \\
-6 \text { animals received Radix } \\
\text { astragali and Angelica } \\
\text { sinensis } \\
\text { sinensis and PZQ } \\
\text { miltiorrhiza, Angelica } \\
\text { astragali, Salvia }\end{array}$ & $\begin{array}{l}\text { S. japonicum, } 100 \\
\text { cercariae, } \\
\text { percutaneous route }\end{array}$ & $\begin{array}{c}\text {-Treatment started } \\
18 \text { weeks post } \\
\text { infection, } \\
\text {-Weekly USG } \\
\text { from week } 13 \\
\text { until week } 28\end{array}$ & $\begin{array}{l}\text {-Assessment of HSS } \\
\text { in liver (liver } \\
\text { diameter, PV inner } \\
\text { diameter, echogenic } \\
\text { septa forming } \\
\text { mosaics, echogenic } \\
\text { spots) } \\
\text {-Assessment of serum } \\
\text { markers of fibrosis } \\
\text { and liver function } \\
\text {-Comparison of the } \\
\text { effects of traditional } \\
\text { Chinese medicines to } \\
\text { PZQ on liver fibrosis }\end{array}$ & $\begin{array}{l}\text { Validation of the } \\
\text { rabbit model of HSS } \\
\text { obtained with } S \text {. } \\
\text { japonica } \\
\text { Beneficial effects of } \\
\text { traditional Chinese } \\
\text { medicines on liver } \\
\text { fibrosis }\end{array}$ & $\begin{array}{l}\text { Assessment of } \\
\text { antifibrotic drug } \\
\text { effects in a good } \\
\text { model of the human } \\
\text { disease resulting } \\
\text { from S. japonicum } \\
\text { infection }\end{array}$ \\
\hline
\end{tabular}




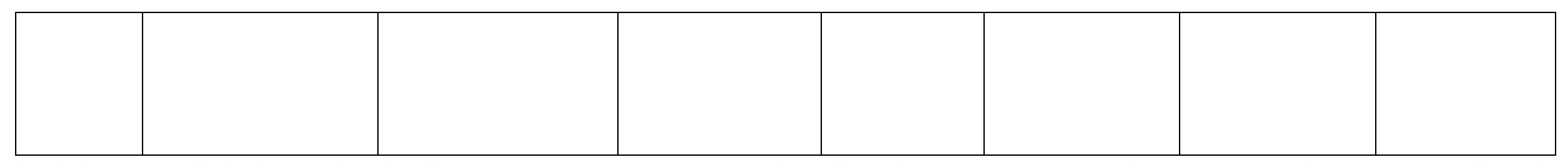

Abbreviations: BLI = bioluminescent imaging; $\mathrm{CT}=$ computed tomography; $\mathrm{EPX}=$ eosinophil peroxidase promoter; FMT= Fluorescence molecular tomography; LSM= Liver

Stiffness Measurement; luc= luciferase; $\mathrm{MRI}=$ magnetic resonance imaging; $\mathrm{PET}=$ positron emission tomography; $\mathrm{PH}=$ portal hypertension; $\mathrm{PV}=$ portal vein; $\mathrm{PZQ}=$

praziquantel; SPECT= Single-photon emission computed tomography; USG = Ultrasonography. 
A

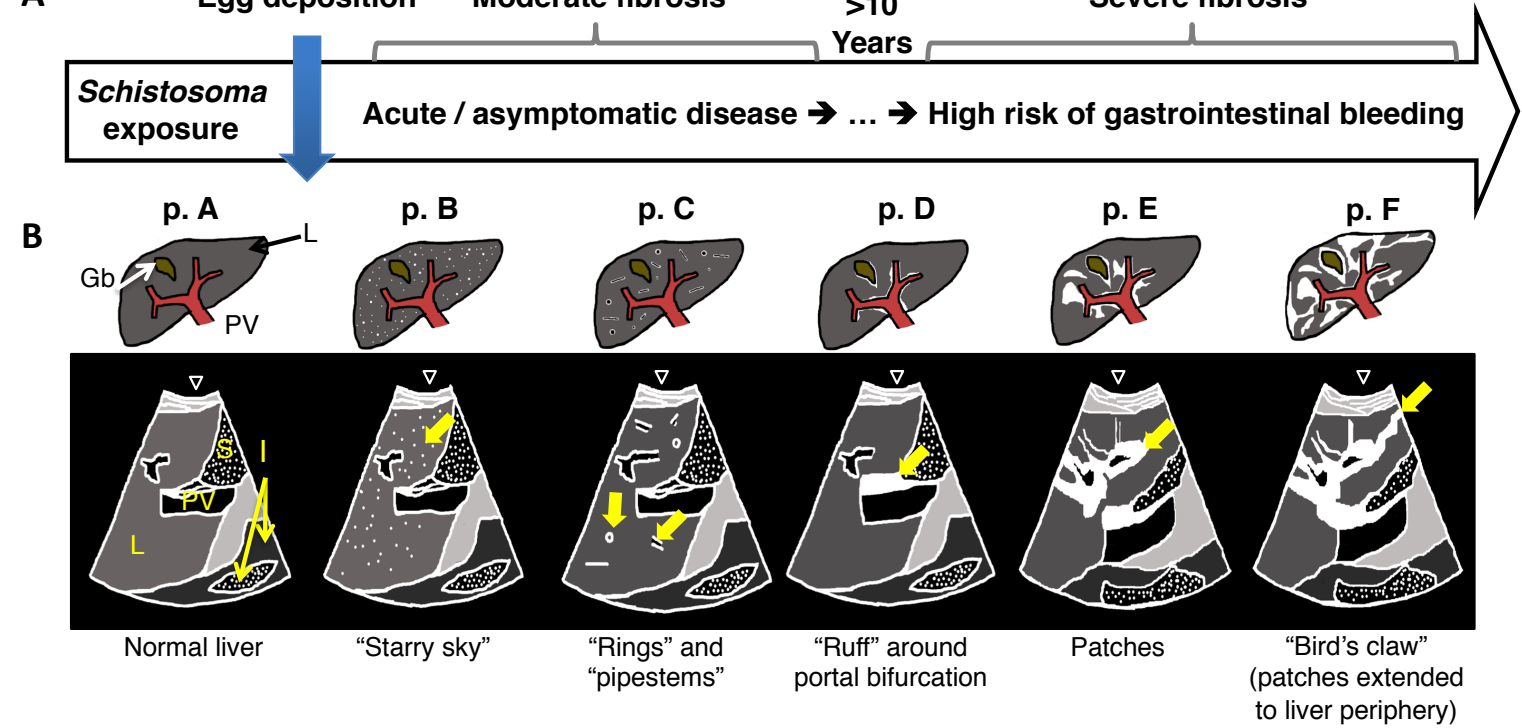

$\nabla=$ USG probe location $\mathbf{G b}=$ Gallbladder

I = Intestine

$\mathbf{L}=$ Liver

PV $=$ Portal Vein

$\mathbf{S}=$ Stomach

Digestive lumen

Vessel lumen

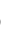

C

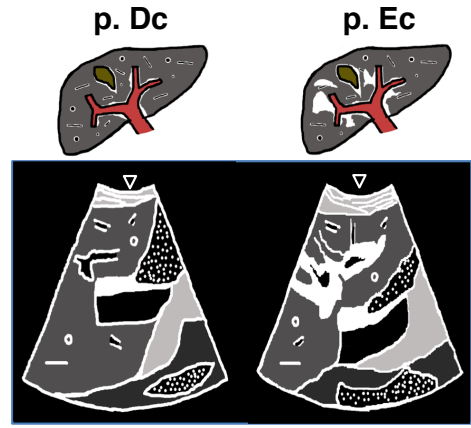

D

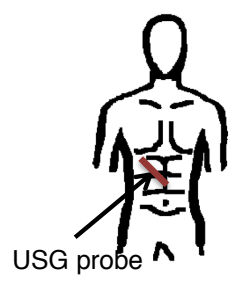

(1)

(1)

Figure 1, Key Figure. Schematic representations of typical USG images in HSS and

corresponding patterns based on Niamey classification. A. Temporal progression of HSS.

B. Illustration of the different stages of HSS with Niamey classifications patterns (top row) and

corresponding schematic representations of USG images (bottom row). The right oblique ultrasound probe orientation allows visualisation of the hepatic hilar area with the portal vein (PV) and surrounding vessels. This view allows detection of periportal fibrosis (pattern D to Ec) and measurement of PV diameter as well as evaluation of hypertension (dashed line in D, E and F patterns). Pattern B (p. B) also named "Starry sky" corresponds to echogenic spots in liver parenchyma caused by inflammation and fibrosis around granuloma. Pattern C (p. C) shows echogenic signals around portal branches and represents a moderate stage of fibrosis. Acute or/and asymptomatic phases are assigned to B and C patterns. Large fibrosis areas in 
1 parenchyma, described as "patches", are associated with E pattern. Fibrosis extension to the 2 liver periphery from patches was described as "Bird's claw" and assigned to F pattern. C. Dc 3 and EC are examples of combined patterns. D. Right echographic oblique view presented in B. 4 